\title{
Equine endometritis: a review of challenges and new approaches
}

\author{
Lee H A Morris ${ }^{1}$, P M McCue ${ }^{2}$ and Christine Aurich ${ }^{3}$ \\ ${ }^{1}$ EquiBreed NZ Ltd, Te Awamutu, New Zealand, ${ }^{2}$ Department of Clinical Sciences, Colorado State University, Fort \\ Collins, Colorado, USA and ${ }^{3}$ Centre for Artificial Insemination and Embryo Transfer, Vetmeduni Vienna, \\ Vienna, Austria
}

Correspondence should be addressed to L H A Morris; Email: lee@equibreed.co.nz

\begin{abstract}
Endometritis in the mare begins as a normal physiological inflammatory response to breeding that involves both a mechanical and immunological response pathway activated to rid the uterus of semen and bacteria. With successful resolution of this inflammation, the mare's uterus will provide a hospitable environment for the development of the semi-allogenic conceptus. If the mare fails to resolve this inflammatory response within $\mathbf{4 8} \mathrm{h}$ of breeding, she will become susceptible to persistent breeding-induced endometritis (PBIE) which will have detrimental effects on her fertility. This condition can then predispose the mare to bacterial or fungal endometritis leading to further degeneration of the endometrium. Optimisation of the mare's fertility requires a fine balance between allowing the natural immune response of the endometrium to its exposure to allogenic semen to run its course, and yet preventing its progression to PBIE or the involvement of infectious agents. This review discusses the challenges presented by PBIE, latent infections, biofilms, fungal infections and the need to utilise diagnostic methods available and implement targeted treatments to optimise fertility in the mare.

Reproduction (2020) 160 R95-R110
\end{abstract}

\section{Background}

'Equine endometritis' is often cited as one of the major causes of infertility in the mare (Troedsson 1999, Liu \& Troedsson 2008, LeBlanc 2010, Troedsson \& Woodward 2016, Canisso et al. 2020). More recently, however, endometritis itself has been defined as a normal immunological response to the introduction of semen into the mare's reproductive tract during breeding. In normal, fertile mares this physiological inflammation resolves with the successful removal of uterine fluid, semen and bacteria within $48 \mathrm{~h}$ of breeding. However, if this inflammation remains unresolved beyond $48 \mathrm{~h}$, then the pathological condition of persistent breeding-induced endometritis (PBIE) ensues (Christoffersen \& Troedsson 2017, Canisso et al. 2020). If PBIE remains unchecked, the condition results in immense inflammation and may progress to infectious endometritis or the development of endometrial fibrosis (Fig. 1).

Clinically, a presumptive diagnosis of persistent breeding-induced endometritis is made if more than 2 $\mathrm{cm}$ uterine fluid is detected by ultrasound during oestrus (Brinkso et al. 2003) or within 36 h after breeding (LeBlanc 2010). The incidence of uterine fluid retention within $30 \mathrm{~h}$ of natural service in a population of intensively managed thoroughbreds has been reported to range from 15\% (Zent et al. 1998) to 30\% (Pycock \& Newcombe 1996). It is worth noting that this ultrasound evaluation typically provides a 'presumptive diagnosis' made prior to the development of PBIE, and prophylactic treatment may be implemented. Furthermore, unless the mare fails to conceive, the diagnosis of PBIE under field conditions does not routinely involve detailed cytological, microbial or histological examination. In addition, the optimal time to administer uterine treatments, within $48 \mathrm{~h}$ postbreeding, is prior to closure of the cervix after ovulation. Consequently, culture and sensitivity results of uterine samples may not be available in time to make clinical decisions. Ultimately, these factors limit our ability to determine the actual incidence of PBIE in a commercial breeding population.

In the field, the first cycle pregnancy rate in thoroughbreds has been reported to range from 53 (Hanlon et al. 2012) to 68\% (Nath et al. 2010), which translates to a failure of conception in some $32-47 \%$ of cycles. Mares that fail to conceive and older mares are more likely to receive uterine treatment within $48 \mathrm{~h}$ after breeding (Morris \& Allen 2002, Allen et al. 2007, Riddle et al. 2007). In less than 10 years, in similar populations of mares, there has been an increase in the percentage of mares that receive intrauterine treatment, from 9 (Morris \& Allen 2002) to 26.3\% in 3- to 8-year-old mares (Allen et al. 2007), and from 24\% (Morris \& Allen 2002) to $51.3 \%$ in mares $>18$ years of age (Allen et al. 2007). Furthermore, Allen et al. (2007) reported that antibiotics comprised $24.6 \%$ of postservice treatments. To slow the 


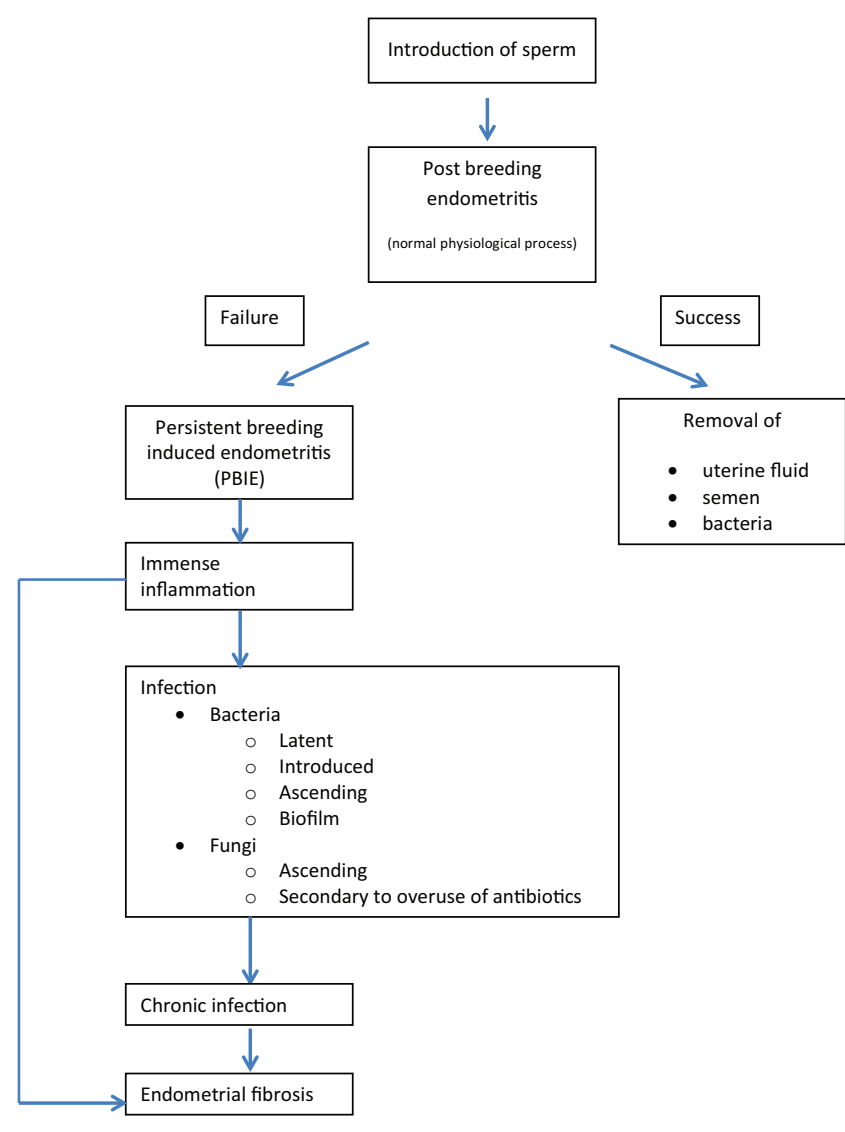

Figure 1 The success and failure of postbreeding endometritis in the mare.

emerging resistance to antibiotics, which has resulted from the overuse of antibiotics, the 'One Health' philosophy (https://www.oie.int/en/) to veterinary medicine has been developed. It is recommended that antibiotics only be used in cases of bacterial endometritis confirmed by positive bacterial culture. As such, the diagnosis and application of effective treatment of PBIE is now more important than ever.

A multitude of factors predispose mares to PBIE, the major ones being advancing age, poor perineal conformation, repeat breeding and dystocia (Watson 2000, Christoffersen et al. 2015b). Upon ruling out other causes of infertility, an effective breeding management strategy will reduce the risk of PBIE and implement evidence-based treatment to optimise fertility. To this end, this paper will review our current understanding of the physiology of endometritis and how treatments work to prevent and manage the development of PBIE.

\section{Pathophysiology of persistent breeding-induced endometritis}

After natural mating or insemination, normal mares typically exhibit some degree of physiological inflammation that resolves within $48 \mathrm{~h}$ of exposure to semen (Katila 1995, Watson et al. 2001, Christoffersen et al. 2012, Fedorka et al. 2018). The resolution of this inflammation relies on the effective coordination of several response pathways, with (1) a mechanical pathway involving myometrial contractions to physically evacuate inflammatory debris, and (2) the innate immune response being the major mechanisms to eliminate excess spermatozoa and bacteria while (3) the classical immunological antigen-antibody response is minimal and thus of minor importance in mares (Fig. 2). Together, these pathways work to prevent the establishment of PBIE. Mares that are resistant to PBIE display efficient uterine clearance mechanisms and their transient endometrial inflammation ceases within 24-36 h after breeding, allowing an embryo-friendly uterine environment to become established prior to entrance of the conceptus into the uterine lumen some five days later. Mares which fail to resolve their physiological postbreeding endometritis are deemed to become 'susceptible' to PBIE which predisposes them to secondary uterine infection (Pycock \& Allen 1990).

\section{Mechanical pathway}

During mating or insemination, the mechanical stimulation of the cervix and vagina initiates a release of oxytocin which stimulates myometrial contractions that need to be maintained for effective expulsion of fluid from the uterine lumen (Campbell \& England 2004, Risco et al. 2009) through the cervix and into the vagina during the ensuing 6-12 h (Troedsson 1997). After ovulation and cervical closure, any remaining uterine particulate matter, oedema and inflammatory cells are drained via the lymphatics within the endometrium (LeBlanc et al. 1995). This mechanical process may be impaired by the existence of acquired anatomical defects such as poor perineal conformation, vaginal stretching, an incompetent cervix, a pendulous uterus, or degenerative defects of the myometrium and/or endometrium. Such physical changes develop in association with repeated mating and foaling, or increasing age of the mare (Evans et al. 1987, LeBlanc et al. 1989) and increase the susceptibility of the mare to PBIE.

Mares susceptible to PBIE may also have delayed or reduced myoelectrical activity in the myometrium, which interferes with the clearance of uterine contents (LeBlanc et al. 1994b). This myometrial activity is influenced by a combination of marefactorsandimmunological, endocrine and chemical factors associated with inflammation. After deposition of spermatozoa and bacteria into the uterus, the PMN-phagocytosis of spermatozoa and/or bacteria results in inflammation that produces arachidonic acid metabolites, including $\mathrm{PGF}_{2 \alpha}$, which also causes myometrial contractions (Troedsson 1999). Mare age influences the response of the myometrium to oxytocin and prostaglandins by altering receptor-second messenger signalling mechanisms downstream of the intracellular 


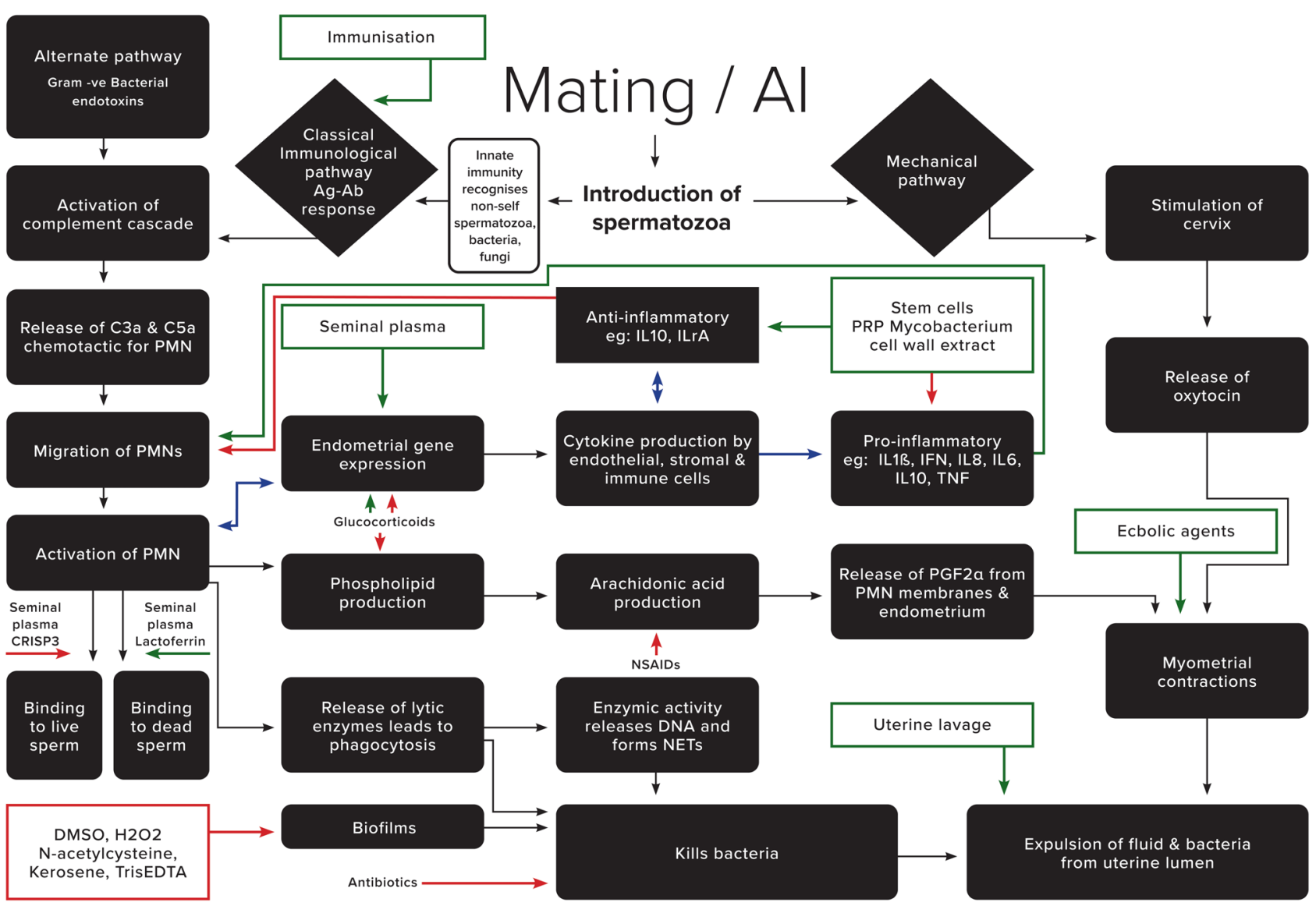

Figure 2 The pathogenesis of endometritis in the mare. Key: inhibition, modulation, stimulation. Red arrows indicate inhibition, blue arrows indicate modulation and green arrows indicate stimulation.

$\mathrm{Ca}(2+)$ release (Rigby et al. 2001). Then, superimposed on these age and endocrine factors, chemical factors such as the accumulation of nitric oxide (NO) in the uterus of susceptible mares (Alghamdi et al. 2005) have been suggested to contribute to the pathogenesis of impaired myometrial activity (Woodward et al. 2013b, Khan et al. 2017).

Any interference in the evacuation of uterine fluid through the cervix and lymphatics after mating contributes to the progression of endometrial degenerative changes (Woodward et al. 2012, Reilas et al. 2016). The ensuing endometrosis contributes to a vicious cycle involving severe inflammation, which causes fibrosis and subsequent fluid accumulation. Angiopathies impair blood circulation and lymphatic lacunae interfere with fluid circulation. Dysfunctional mechanical clearance of any uterine inflammatory by-products then undermines the mare's uterine defence (LeBlanc et al. 1994b, LeBlanc \& Causey 2009, Katila 2012, 2016) and predisposes her to bacterial or fungal endometritis.

\section{Immunological pathway}

Aftertheintroduction ofspermatozoaintothereproductive tract, the innate immune response provides the first https://rep.bioscientifica.com natural, nonspecific defence response and involves phagocytic cells such as neutrophils, macrophages and dendritic cells. Troedsson (1999) suggested that the uterine defence system is not dependent on humoral factors until later when the antibody-mediated response is required to eliminate bacterial contaminants from the uterus. Indeed, the concentrations of immunoglobulins (IgA, M and G) in uterine secretions are similar throughout all stages of the oestrous cycle in normal mares and are only elevated in mares susceptible to endometritis (Waelchli \& Winder 1987). However, during oestrus, the dominance of oestrogen contributes to the expression of immune-related genes required to manage the immune response to the uterine deposition of foreign material, spermatozoa and bacteria, during breeding (Asbury \& Hansen 1987, Skarzynski et al. 2020).

Both spermatozoa and bacteria have similar allogenic, pathogen recognised receptors which activate the innate immune pathway that is mediated by tolllike receptors (TLR) on epithelial cells and serves to prevent the establishment of infection until antigenspecific cells are recruited to the local site (Schöniger et al. 2017, Ezz et al. 2019, Skarzynski et al. 2020). These responses are antigen-nonspecific, rapid, and are based on recognition of invariant molecular structures 
on pathogens known as pathogen-associated molecular patterns (PAMPS), which include the lipopolysaccharide (LPS) of Gram-negative bacteria and peptidoglycan and lipotechoic acid of Gram-positive organisms (Quayle 2002). This innate immune response enables allogenic spermatozoa to challenge the immune system without developing anti-sperm antibodies (Canisso et al. 2020). The dendritic cells are the link between the innate and adaptive immune response. So when antigenic foreign proteins are present, both $\mathrm{T}$ and $\mathrm{B}$ cells are activated via dendritic presentation, followed by the complement cascade and initiation of polymorphonuclear leukocyte (PMN) chemotaxis (Troedsson 1999) which aids the removal of non-viable spermatozoa and pathogenic bacteria.

The PMN infiltration occurs in the uterus from 0.5 $\mathrm{h}$ after breeding to its peak within 4-8 h (Katila 1995). Once activated, the PMNs release lytic enzymes that result in phagocytosis of bacteria. This enzymatic activity ensures the release of DNA from the PMN and the production of neutrophil extracellular traps (NET) which have immunomodulatory and bacteriocidal effects (Rebordao et al. 2014).

During mating or insemination the mare's endometrium is exposed to seminal plasma which has an immunomodulatory role in the endometrial response to spermatozoa. Seminal plasma increases the mRNA expression of some pro-inflammatory cytokines (e.g. IL-8, IL-1 $\beta$ ) while suppressing others (e.g. TNF) (Fedorka et al. 2017) in the endometrium (Fig. 2). Although seminal plasma is not necessary for normal mares to achieve satisfactory pregnancy rates (Portus et al. 2005), when it is combined with spermatozoa it facilitates the uterine clearance of PMN by suppressing complement activation, PMN chemotaxis and phagocytosis (Fiala et al. 2007, Troedsson \& Woodward 2016). This finely balanced immunomodulation by seminal plasma is made possible by the existence of one of its cysteinrich secretory proteins, CRISP-3, which prevents PMNbinding and phagocytosis of viable spermatozoa, and enables the completion of sperm transit within a transitionally inflamed uterus over the next $4 \mathrm{~h}$ (Doty et al. 2011). Whereas lactoferrin in the seminal plasma appears to increase binding of dead spermatozoa to PMNs in vitro (Troedsson et al. 2014). Indeed, the removal of seminal plasma has a detrimental effect on the immune response to insemination (SánchezRodríguez et al. 2018).

During the first $24 \mathrm{~h}$ after breeding, there is also a rapid increase in the pro-inflammatory cytokines, IL1 $\beta$, IL-8 and IFN- $\gamma$, as well as activation of PMNs to bind to and engulf bacteria and spermatozoa (Christoffersen et al. 2012). This physiological inflammatory reaction further serves to eliminate contaminating bacteria, debris, seminal plasma and excess spermatozoa from the uterine lumen (Kotilainen et al. 1994, Katila 1995, LeBlanc \& Causey 2009, Christoffersen \&
Troedsson 2017). In response to the inflammation, antiinflammatory cytokines (IL1RA, IL10) are released to mediate the response.

The cessation of the physiological inflammatory endometrial response to mating requires a balance between both pro- and anti-inflammatory factors, which is observed between 6 and $12 \mathrm{~h}$ after breeding in mares that are resistant to PBIE (Woodward \& Troedsson 2015, Marth et al. 2018a). In contrast, mares susceptible to PBIE fail to clear the endometrial inflammation within this timeframe and are also prone to bacterial infection (Hughes \& Loy 1969, LeBlanc et al. 1989). In these susceptible mares, endometrial expression of proinflammatory cytokines is inadequate and prolonged, and they exhibit lower mRNA expression for the antiinflammatory cytokines (ILRA, IL10, IL6) and higher mRNA expression for the pro-inflammatory cytokines (e.g. IL1 $\beta$, IL-8) after breeding. This cytokine imbalance leads to an increased number of PMNs observed within the uterus between 2 and $12 \mathrm{~h}$ after breeding (Christoffersen et al. 2012, Woodward et al. 2013a, Christoffersen \& Troedsson 2017).

\section{Infectious endometritis}

Every time a mare is mated or inseminated her natural physical barriers to infection, the vulval opening, vagino-vestibular junction and cervix, are breached and bacteria are introduced. In the last 80 years, one of the earliest and most effective strategies to minimise the introduction of bacteria into the reproductive tract and improve conception rates has been the use of the Caslick vulvoplasty which contributes to improved pregnancy rates (Caslick 1937).

\section{Bacterial factors in endometritis}

If the mare fails to resolve her physiological endometritis and she develops PBIE, the immense inflammation, if combined with a concurrent challenge from pathogenic organisms, may progress to infectious endometritis (Hughes \& Loy 1969, Christoffersen \& Troedsson 2017). These pathogenic organisms may be latent, deep within the endometrial glands (Petersen et al. 2018), introduced at mating, or ascend from the caudal genital tract to cause infectious endometritis (Davis et al. 2013). The postbreeding physiological inflammatory response itself may activate latent bacteria (Petersen et al. 2015).

It has been reported that up to $60 \%$ of barren mares have been diagnosed with bacterial endometritis (LeBlanc \& Causey 2009). The most common bacteria isolated from the uteri of mares include Escherichia coli and Streptococcus equi subsp. zooepidemicus ( $S$. zooepidemicus) (LeBlanc \& Causey 2009, Davis et al. 2013, Christoffersen et al. 2015b). Davis et al. (2013) isolated bacteria from 22 to $43 \%$ of more than 8000 uterine samples and from these, there was a similar 
incidence of S. zooepidemicus (29\%) and E. coli (28\%). However, only $62 \%$ of Streptococci and $43 \%$ of E. coli positive cases had concurrent evidence of cytological inflammation, thus complicating the diagnosis as contamination remained a possibility (Davis et al. 2013).

$S$. zooepidemicus is one of several $\beta$-haemolytic Streptococci associated with infectious endometritis. Other species of Streptococci, including S. dysgalactiae subsp. equisimilis and $S$. equi subsp. equi (S. equi), have also been isolated from the equine endometrium (Albihn et al. 2003, Christoffersen et al. 2015b). However, specific reproductive strains of $S$. zooepidemicus are opportunistic and reside in the caudal reproductive tract until they produce disease in response to tissue damage (Timoney 2004), as occurs during PBIE. These isolates belong to a genetically distinct subpopulation (Rasmussen et al. 2013, Christoffersen et al. 2015b), that differ from respiratory or abortive strains (Timoney 2004). In older, multiparous mares with poor vulval conformation, isolation of a single strain of $S$. zooepidemicus (clonal infection) can also occur (Christoffersen et al. 2015b).

Specific strains of $S$. zooepidemicus are highly pathogenic by virtue of the expression of super-antigens (Casagrande Proietti et al. 2011). These pathogenic strains of S. zooepidemicus (Rasmussen et al. 2013) persist deep in the uterine glands in the stratum compactum (Petersen et al. 2015) or intracellularly (Skive et al. 2017) in the endometrium in chronically infected mares. Here, the streptococci employ the anti-phagocytic hyaluronic acid capsule in addition to fibronectin-binding proteins to avoid the host immune response (Timoney 2004, Petersen et al. 2009). These dormant streptococci are not detectable by standard bacterial culture techniques, but can be activated by PBIE and acute infectious endometritis ensues (Petersen et al. 2015).

Unlike Streptococcus spp. and despite the frequency of isolation of $E$. coli, no uterine-specific strains of $E$. coli have been reported in the horse as occurs in cattle (Sheldon et al. 2010), suggesting that $E$. coli are most likely contaminants and do not reside in the equine uterus. In addition to E. coli and S. zooepidemicus, other bacteria, fungi and yeasts may also cause infectious endometritis. Some of these other infections are iatrogenically introduced environmental contaminants, venereal pathogens or secondary to over-treatment with antibiotics. These pathogens may be rare, but highly pathogenic. For example, Pseudomonas aeruginosa can be either an opportunistic environmental or venereal pathogen (Blanchard et al. 1992, Allen et al. 2011, Kidd et al. 2011).

\section{Biofilm and biofilm-associated uterine infections}

A biofilm comprises an aggregate of microbial cells adherent to a surface, embedded within a complex matrix of extracellular polymeric substances (EPS) which may also include nucleic acids, proteins, polysaccharides and lipids of microbial origin, as well as host components (Costerton et al. 1999, Koo et al. 2017). Many Gram-negative bacterial pathogens (E. coli, P. aeruginosa and Klebsiella pneumoniae) isolated from the equine uterus can produce biofilm (Ferris et al. 2014b, 2016, Beehan et al. 2015, Brock et al. 2017). It is also possible that equine $S$. zooepidemicus can produce a biofilm, similar to that of $S$. zooepidemicus of porcine origin (Yi et al. 2014).

Bacteria living within a biofilm are physiologically distinct from free-floating (planktonic) organisms of the same species, which influences their susceptibility to treatment (Ferris 2017). Planktonic bacterial infections are readily detected and eliminated by the host immune system or when an appropriate antibiotic is used. However, in their biofilm state, bacteria exist in aggregates embedded within a complex matrix of extracellular polymeric substances, which may include nucleic acids, proteins, polysaccharides and lipids of microbial origin, as well as host components and they typically adhere to surfaces (Costerton et al. 1999, Koo et al. 2017). As such, bacteria in a biofilm are protected from the host immune system as white blood cells and antibodies have reduced ability to penetrate the thick layer of EPS within the biofilm (Thurlow et al. 2011). The bacteria within the biofilm survive with depressed metabolism and lower replication rates than planktonic bacteria (Stewart \& Costerton 2001, Walters et al. 2003). In addition, bacteria in a biofilm may be 10-1,000 times more resistant to antibiotic treatment than planktonic bacteria (Mah \& O'Toole 2001).

Antibiotics typically only act against metabolically active and/or rapidly multiplying bacteria, therefore, bacteria in the outer regions of the biofilm may be killed, but those deep within the biofilm survive and become the nidus for recurrence and development of a chronic infection (Olsen 2015). Their reactivation results in recurrence of clinical infection. It is of concern that horizontal transfer of antibiotic resistance genes may occur between bacteria while protected within a biofilm (Olsen 2015).

Biofilm-associated infections are typically difficult to diagnose and challenging to treat and rates of recurrence are high. Traditional antibiotic therapy, both systemic and local, are often ineffective against bacteria residing within a biofilm (Beehan et al. 2015) and so therapy includes biofilm disrupters in combination with antibiotics.

\section{Fungal endometritis}

Fungal organisms are reported to occur in $1-5 \%$ of mares diagnosed with infectious endometritis (Dascanio et al. 2001) and are predisposed by overuse of antibiotics and physical conditions such as pneumovagina, urovagina, decreased uterine fluid clearance, cervical defects, immunosuppression, necrotic foci and perineal defects 
(Dascanio et al. 2001, Stout 2008). Overuse of antibiotics in the treatment and/or prevention of PBIE effectively alters the normal flora of the caudal reproductive tract, and facilitates fungal colonisation of the vaginal vault, clitoral fossa and clitoral sinuses (Zafraca 1975, Blue 1987). The most commonly cultured fungal organisms are the yeast, Candida spp., and mould/hyphate organisms, such as Aspergillus spp. and Mucor spp. (Coutinho da Silva \& Alvarenga 2011). Fungal endometritis in mares is often chronic in nature, difficult to diagnose, difficult to eliminate and associated with a high incidence of recurrence.

\section{Diagnosis of endometritis}

The diagnosis of postbreeding endometritis in a clinical setting typically involves examination of the reproductive tract within $48 \mathrm{~h}$ after breeding (LeBlanc 2010). Clinically it is important to diagnose predisposing causes and to prevent the progression of PBIE to infectious endometritis. The physical signs of endometritis include a vulval discharge, cervical discharge visualised by vaginal speculum examination and uterine fluid accumulation as detected by ultrasound examination per rectum. Depending on the signalment of the mare, consideration of her age, parity, perineal conformation, cervical tone, reproductive status, foaling history, history of infection and the fertility of the stallion, after mating or insemination, the clinician may progress to laboratory-based tests to obtain evidence of a cytological response and identify any microbial organisms and their antimicrobial sensitivity. Further investigation may also include hysteroscopy or histological evaluation, and in some cases culture of an endometrial biopsy. New diagnostic methods are being developed that include confocal imaging for real-time 'biopsy' during hysteroscopy that will provide rapid diagnosis from detailed histological information about the inflammatory changes in the endometrium (Gallacher et al. 2018). Additional haematological and serum biochemistry tests are not considered useful indicators of equine endometritis due to the local nature of postbreeding endometritis (Katila 2016).

The sensitivity and specificity of laboratory diagnostic methods, including culture swabs, cytobrush, low volume lavage and uterine biopsy, have been reviewed (Katila 2016). Several studies conclude that low volume lavage is the most sensitive test for diagnosis of a bacterial endometritis (Christoffersen et al. 2015a, Katila 2016). Riddle et al. (2007) reported that the recovery of either 2-5 PMNs per 400x field, and/or a bacterial monoculture is deemed diagnostic of endometritis and has been associated with reduced pregnancy rates. The pathogenicity of the bacteria will influence the cytology results such as incurred by $E$. coli infections which can suppress the PMN response, or by the latency of Streptococci spp., which have not induced a PMN response (LeBlanc 2010, Christoffersen et al. 2015a, Petersen et al. 2015). The opportunistic behaviour of pathogenic bacteria may also vary depending on the fragile balance of the normal flora or microbiome (Heil et al. 2019).

Recently, genome sequencing has identified Proteobacteria as the predominant species in the normal microbiome in fertile mares (Heil et al. 2018) and it is hypothesised that any shift in this population may lead to an increased risk of PBIE and bacterial endometritis. New qPCR diagnostic methods are also being developed which have a high sensitivity and specificity to identify mares that are susceptible to postbreeding endometritis by diagnosis of innate immune genes including equine $\beta$ defensin 1 (EBD1), lysozyme (LYZ) and secretory leukoprotease inhibitor (SLP1) which are found in their endometrium (Marth et al. 2018a,b).

\section{Diagnosis of fungal endometritis}

If PBIE remains unresolved, there is an increased risk of mares developing fungal endometritis. Mares with fungal endometritis often have a history of chronic infertility and clinical signs may include a purulent vaginal discharge and an excess of echogenic fluid within the uterine lumen (Scott 2019). Currently, the standard techniques for detection of fungal infections are mycological culture, evaluation of endometrial cytology, uterine biopsy and detection of fungal DNA by PCR analysis (Dascanio et al. 2001, Stout 2008, Ferris et al. 2013, Scott 2019).

Fungal agents are often easiest to detect in cytology smears made after centrifugation of uterine effluent from a low-volume lavage. Yeasts are typically recognised by their 5-8 $\mu \mathrm{m}$ diameter and their distinct cell wall (100$200 \mathrm{~nm}$ ) forming a clear 'halo' around the organism. Hyphate fungi are narrower, $3-5 \mu \mathrm{m}$ in width and $8 \mu \mathrm{m}$ in length. These individual cells are commonly linked in long branching chains. In many instances, detection of a fungal organism on cytological examination may be the only evidence of fungal endometritis, since these organisms do not always grow in culture (Beltaire et al. 2012). Mares with fungal endometritis will often, but not always have inflammatory cells in the cytology sample. Fungal elements can also be detected within uterine biopsy samples stained with Gomon's methamine silver stain or periodic acid-Schiff (PAS) stain (Scott 2019). Analysis of uterine biopsies also provides useful information about the degree of inflammation associated with the infection (Coutinho da Silva \& Alvarenga 2011).

Mycological culture is often reserved for difficult cases of infectious endometritis because it requires 3-4 weeks of culture to allow for the long growth phase of mycotic organisms and accurate identification. To optimise diagnosis, Sabouraud's dextrose agar is recommended to culture fungal organisms since a high percentage 
do not grow under normal aerobic conditions in agar (Beltaire et al. 2012). Ideally, selection of an antifungal agent would be based on the results of susceptibility tests for the specific fungal organism (Dascanio et al. 2001). Unfortunately, due to the time involved in diagnosis, empirical treatment choices are usually implemented. A more rapid and accurate molecular PCR diagnostic method for fungal infections would be useful clinically (Ferris et al. 2013). However, qPCR is limited because it cannot be used to determine antimicrobial susceptibility for fungal organisms. After treatment, it is common for a secondary infection of bacteria such as $S$. zooepidemicus to develop. Consequently, it is often necessary to treat for bacterial endometritis along with, or after, treatment for fungal endometritis.

\section{Management to prevent PBIE}

In a well-managed breeding programme the incidence of PBIE in mares will be minimised and this will lead to a reduced reliance on antibiotics. Modern oestrous management aims to breed mares just once per cycle, not only to improve efficiency but also to allow time for the resolution of normal postbreeding endometritis without repeated antigenic stimulation from semen (Canisso et al. 2016). Nevertheless, multiple inseminations with fresh or frozen semen during oestrus have also be known to improve pregnancy outcomes in fertile mares without increasing the risk of postbreeding endometritis (Voss et al. 1979, Huber et al. 2019). Uterine fluid accumulation was not associated with the timing of insemination between $12 \mathrm{~h}$ before and $8 \mathrm{~h}$ after ovulation (Watson et al. 2001). The choice of insemination method might also contribute to minimising PBIE. Recently, it has been reported that deep uterine insemination results in less inflammation than conventional insemination into the uterine body (Cazales et al. 2018). Despite this, there appears to be an interaction between insemination technique and mare fertility as in another study conventional intrauterine insemination produced better fertility in problem mares and hysteroscopic insemination was better in normal mares (Sieme et al. 2004).

\section{Treatment options}

The objectives of any treatment of PBIE include diagnosis of the causative agent or predisposing factor and to ensure a nurturing uterine environment for embryonic development. Clinically, the dilemma is optimising the timing of treatment to prevent progression of physiological inflammation to the pathogenic condition of PBIE. The most popular strategies to prevent PBIE include a combination of ecbolic and uterine lavage treatment within $48 \mathrm{~h}$ of breeding, which act on the mechanical response pathway and aid the physical removal of inflammatory debris and/or micro-organisms (Pycock \&
Newcombe 1996, LeBlanc \& Causey 2009, Rose et al. 2018). This fundamental strategy may be supplemented with treatments that act on the immunological response pathway such as anti-inflammatory medication (Rojer \& Aurich 2010), antibiotics (Pycock \& Newcombe 1996, Rose et al. 2018), mucolytics (Gores-Lindholm et al. 2013) and immunomodulation therapies (Woodward et al. 2015). Ultimately, the challenge of any therapy must enhance fertility and not cause harm to either the mare or public health (e.g. development of antimicrobial resistance), so an understanding of the indications, mechanism and role of the selected therapy is important.

\section{Treatments targeting the mechanical response pathway}

\section{Ecbolic agents}

In oestrous mares, uterine clearance is improved by the administration of ecbolic drugs, such as oxytocin and prostaglandin (PG) $F_{2 \alpha}$. Injection of oxytocin at the recommended dose of 10 to 25 units results in high-amplitude myometrial contractions for a period of approximately $30 \mathrm{~min}$ in most mares. The effect is greatest during oestrus, but still present for $48 \mathrm{~h}$ after ovulation (LeBlanc et al. 1994a, LeBlanc \& Causey 2009). During oestrus there is higher oxytocin receptor gene expression in the myometrium compared to the luteal phase (Annandale et al. 2018). Interestingly, factors often associated with impaired uterine clearance like mare age or chronic endometrial degeneration do not influence uterine oxytocin receptor expression (Annandale et al. 2018). Nevertheless, the efficacy of oxytocin is reduced if concurrent anatomical conditions exist like a pendulous uterus or closed cervix. Increasing the dose beyond recommended levels is not advisable and may induce inappropriate uterine contractions that do not allow for uterine drainage (LeBlanc \& Causey 2009). However, the synthetic oxytocin analogue, carbetocin, has become an attractive alternative for oxytocin therapy due to its half-life being more than twice that of oxytocin (Schramme et al. 2008).

Among the $\mathrm{PGF}_{2 \alpha}$ analogues studied for their ecbolic

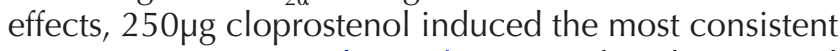
uterine response (Combs et al. 1996). After cloprostenol treatment, uterine contractions were weaker than after oxytocin treatment, but they lasted for up to $4 \mathrm{~h}$. Due to the detrimental effects of $\mathrm{PGF}_{2 \alpha}$ on luteal function and progesterone secretion required for pregnancy maintenance, it is not recommended as an ecbolic postovulation (LeBlanc \& Causey 2009).

\section{Uterine lavage}

The physical removal of fluids and inflammatory debris by uterine lavage after insemination underpins the prevention and treatment strategy for PBIE. Uterine 
lavage in susceptible mares is indicated when there is hyperechoic intrauterine fluid accumulation or if free intrauterine fluid exceeds two cm in diameter (LeBlanc \& Cousey 2009). The appropriate timing of post-breeding uterine lavage is considered more important than choice of the lavage fluid (Brinsko et al. 1991). Sterile saline or lactated Ringer's solution are commonly used for this purpose (Allen et al. 2007, LeBlanc \& Causey 2009). Neither uterine lavage performed immediately before insemination (Vanderwall \& Woods 2003) or at $4 \mathrm{~h}$ after insemination was detrimental to fertility whereas lavage at 0.5 or two $\mathrm{h}$ after insemination decreased pregnancy rates (Brinsko et al. 1990). While uterine lavage with $0.05 \%$ povidone-iodine solution close to ovulation did not produce inflammation in one study (Brinsko et al. 1990), the addition of $1 \%$ povidone-iodine to uterine lavage fluids caused inflammation (Olsen et al. 1992) and also reduced expression of endometrial progesterone receptors which may have implications for fertility (Kalpokas et al. 2010).

\section{Treatments targeting the immunological response pathway}

As discussed, the physiological inflammation activated within the first few hours after breeding is fundamental to the success of the immunological balancing act required to allow passage of viable, but allogenic spermatozoa, whilst eliminating non-viable spermatozoa and contaminants in order to prepare the uterus for the safe arrival of a semi-allogenic embryo. A major challenge for our therapeutic strategy is that any treatment targeting this immunological pathway must preserve its delicate balance to optimise fertility.

\section{Immunisation}

Immunisation against bacterial infection during breeding would be the holy grail of preventative treatment for bacterial endometritis. By preventing infection, the balanced immunological response would be preserved and our dependence on antibiotics would be reduced. Ongoing studies in mice have identified cell surface protective antigens against $S$. zooepidemicus that may be useful in developing a vaccine to help prevent endometritis (Fu et al. 2013, Xie et al. 2018). In contrast to other species, the mare's uterine defence system relies predominantly on local uterine defence and $\lg \mathrm{A}$ production more than systemic production of IgG (Widders et al. 1985), so a combined preventative approach may be warranted. However, the varied antigenicity and complexity of the virulence factors of S. zooepidemicus will complicate vaccine development (Timoney 2004). Immunisation of mares with a semipurified extract of $S$. zooepidemicus was able to reduce bacteria shedding and improve the immune response of the treated mare to infection when administered both systemically and locally. Reduction in bacterial shedding was greater in mares with higher serum IgG and uterine IgA titres (Widders et al. 1995).

\section{Anti-inflammatory drugs}

Seminal plasma's immunomodulatory role in facilitating sperm transit through the oestrogen primed uterus, make it or its component proteins like lactoferrin, a candidate for PBIE treatment. In mares susceptible to endometritis, supplementation of the inseminate with human recombinant lactoferrin (hrLF) suppressed the endometrial mRNA expression of tumour necrosis factor $\alpha$ at $6 \mathrm{~h}$ after breeding (Fedorka et al. 2017) and of interleukin 6 at $24 \mathrm{~h}$ after breeding (Coutinho da Silva et al. 2017). Subsequently, mares were treated with intrauterine hrLF at $6 \mathrm{~h}$ after mating, at which time the ratio of PMN to endometrial epithelial cells was suppressed (Fedorka et al. 2018). Further evaluation of seminal plasma proteins as therapeutic agents may be warranted for susceptible mares.

latrogenic modulation of either, the phospholipase A2 pathway with glucocorticoid treatment, or the cyclo-oxygenase pathway with NSAIDs treatment may be indicated in susceptible mares to prevent excessive inflammation. Glucocorticoids alter the expression of genes for complement, cytokines, TNF, TGF and major histocompatibility complex (MHC), while NSAIDs inhibit prostaglandin synthesis in response to endometrial inflammation (Wolf et al. 2012). This reduces inflammation and explains the improved fertility observed after glucocorticoid treatment with dexamethasone (Bucca et al. 2008) or prednisolone (Dell'Aqua et al. 2006) in mares susceptible to PBIE. Beneficial effects of NSAID treatment with vedaprofen (Rojer \& Aurich 2010) or firocoxib (Friso et al. 2019) prior to breeding have also been observed. However, given the role of NSAIDs in inhibiting prostaglandin release and their potential to reduce the myometrial contractions required to evacuate uterine fluid, further evaluation of the efficacy of NSAIDs treatment is warranted (Cadario et al. 1995, Risco et al. 2009) and concurrent treatment with an ecbolic such as oxytocin is recommended.

\section{Stem cell treatment}

There is potential for clinical application of stem cells to treat PBIE. The immunomodulatory effects of a uterine infusion of endometrial mesenchymal stem cells (eMSC) have been reported. This treatment reduced the influx of polymorphonuclear neutrophils and increased the induction of anti-inflammatory cytokines (IL-6, IL-8, MCP-1, CCL5, TLR4) in the uterus (Rink et al. 2018). In addition, these eMSC exhibited antimicrobial properties. Treatment of the uterus with stem cells can be performed by either hysteroscopic injection (Fumuso et al. 2014) or uterine infusion (Ferris et al. 2014a, Rink et al. 2018). 
After infusion, the actions of these cells were exerted within the uterine lumen as the eMSC did not migrate into the endometrium itself.

\section{Plasma}

More recently, the use of plasma products has been directed towards immunomodulation rather than elimination of pathogens from the uterus. Platelet-rich plasma (PRP) produces a range of growth factors in vitro that may be useful in treating endometritis (Schar et al. 2015). Administration of PRP $(257,000$ platelets/ $\mu \mathrm{L})$ modulates the uterine inflammatory response to semen and results in reduced inflammation in mares resistant or susceptible to endometritis (Reghini et al. 2014, 2016). Indeed, clinical trials have recently demonstrated the beneficial effects of platelet enriched plasma on pregnancy rates in problem mares (Metcalf 2014). In humans the platelet granules exhibit bacteriocidal activity against Staphylococcus spp., E. coli and Klebsiella spp. (Canisso et al. 2020). Intrauterine treatment with autologous conditioned serum also reduced the infiltration of neutrophils in mares (Ferris et al. 2014a).

\section{Mycobacterium cell wall extract (MCWE)}

Mycobacterium cell wall extract is an immune modulator, comprising two primary ingredients, immunomodulatory trehalose dimycolate and muramyl dipeptide, which targets monocytes and macrophages and modulates the production of various cytokines. Clinically, treatment of susceptible mares with MCWE produced a cytokine profile with higher IL-8 and lower IL-10 than resistant mares, after artificial insemination, and similar to the effects of glucocorticoids (Fumuso et al. 2007). A subsequent study found that expression of IL1-beta mRNA was lower after treatment with either glucocorticoids or MCWE, but there was no effect on IL6, interferon gamma, IL10, or IL1RA cytokines (Woodward et al. 2015).

\section{Anti-microbial treatment}

\section{Antibiotics}

Judicious rather than routine use of antibiotics is now the objective of any treatment of bacterial endometritis (https ://www.avma.org/KB/Policies/Pages/Judicious-Therap eutic-Use-of-Antimicrobials.aspx). The guidelines state that prescription of antibiotics should be based on clinical signs, cytological, culture and antimicrobial sensitivity tests as evidence of bacterial infection (https://www.avm a.org/KB/Policies/Pages/AAEP-Prudent-Drug-Usage-Gu idelines.aspx). One of the challenges in developing a treatment strategy is that identification of the infectious agent is not always consistent with cytological evidence of inflammation as Davis et al. (2013) reported that only
$62 \%$ of $S$. zooepidemicus and $43 \%$ of E. coli infections show cytological evidence of inflammation.

Historically, there has been a preference for intrauterine antibiotic treatment of endometritis rather than a systemic parenteral approach (LeBlanc 2009), in part due to the small risk of side effects of antibiotic treatment on intestinal flora in the horse (Davolli et al. 2018). Intrauterine infusions produce high local concentrations of antibiotic in the uterine lumen (LeBlanc 2009). However, factors such as repeated invasion of the cervix during treatment, inhibition of the antibiotics by inflammatory debris, optimising treatment volume, and non-physiological $\mathrm{pH}$ of antibiotics all contribute to the potential for reduced efficacy, the risk of iatrogenic infection and inflammation as well as increased antimicrobial resistance. Homogeneous distribution of the antibiotic of choice at levels exceeding the minimum inhibitory concentration (MIC) for the target bacteria within the endometrium is required, and recently the efficacy of systemic antibiotic treatment and the relationship between plasma and tissue levels has been demonstrated for ceftiofur (Witte et al. 2010, Scofield et al. 2014), gentamicin, ticarcillin, neomycin, amikacin (Witte et al. 2018) and sulfadiazine and trimethoprim (Davolli et al. 2018). However, extrapolation of pharmacokinetic data for different antibiotics must be tempered with the knowledge that most in vivo clinical trials use healthy mares.

Performing antimicrobial sensitivity testing is a key diagnostic step in uterine infections which ensures that the bacteria are susceptible in vitro to the antibiotic is selected. The culture and sensitivity results of uterine swabs submitted to commercial laboratories have shown how bacterial susceptibility and resistance patterns vary by patient, by region and over time, with degrees of resistance to many of the commonly selected antibiotics, including gentamicin, penicillin, ticarcillin and trimethoprim sulphonamides, are evident (Albihn et al. 2003, Davis et al. 2013, Mitchell et al. 2018). Furthermore, no statistical relationship was observed between the degree of inflammation based on a cytology score and the antibiotic resistance pattern in over 8000 cases (Davis et al. 2013).

\section{Treatment of biofilm-associated uterine infections}

Biofilm producing bacteria pose a challenge to effective treatment. If bacteria are avoiding the host immune system from within a biofilm then the biofilm must be disrupted to enable the antibiotics access to the bacteria. Therefore, the objective in eliminating a biofilm-associated bacterial infection is disruption of the biofilm and killing the associated bacteria (Ferris et al. 2017). Antibiotics alone, or non-antibiotic agents touted to disrupt biofilm alone, are often unable to completely eliminate biofilm-associated bacterial infections alone, and so these two therapeutic approaches are often combined (Fig. 3). Addition of TrisEDTA (TrizEDTA ${ }^{\circledR}$; Dechra Veterinary Products, Overland 
1. Culture the mare's uterus to identify the causative bacteria

2. Perform an antimicrobial susceptibility test to determine the optimum antibiotic

3. Perform a uterine lavage to remove inflammatory debris, bacteria and fluid

4. Combine the optimal antibiotic with a non-antibiotic agent, such as Tris-EDTA or DMSO, in the same syringe
a. TrizEDTA $^{\circledR}$, Dechra Veterinary Products, Overland Park, KS 66211, USA
b. DMSO $99 \%$ purity, Valhoma Corporation, Tulsa, OK 74115, USA

5. Infuse the combination once per day for 3 consecutive days

Figure $3 \mathrm{~A}$ protocol for treatment of chronic uterine infections associated with a biofilm.

Park, Kansas, USA) or DMSO to most common antibiotics enhanced bacterial killing and disruption of biofilm, compared to treatment with the non-antibiotic agent or antibiotic alone (Ferris et al. 2016, Ferris 2017, Loncar et al. 2017). Selection of appropriate combinations of biofilm disrupters and antibiotics must also consider that some treatment combinations (e.g. N-acetylcysteine mixed with an antibiotic in the same syringe) may result in reduced activity of the antibiotic (Ferris et al. 2017).

\section{Alternative non-antibiotic therapies for endometritis}

To address the challenge to reduce our reliance upon routine antibiotic treatments for PBIE and infectious endometritis, non-antibiotic alternatives are being evaluated. However, not all alternative treatments are effective and the optimal concentration or dose must be determined (Loncar et al. 2017). Many of these nonantibiotic treatments claim to provide a multipronged approach on the treatment of PBIE by modulating inflammation in conjunction with some antibacterial properties.

\section{DMSO}

DMSO is well known for its anti-inflammatory actions (Jacob \& Herschler 1983). Solutions of 2.5-30\% DMSO are also reported to be bacteriostatic for Staphylococcus aureus, E. coli, Streptococcus spp. and many Gramnegative bacteria (Santos et al. 2003, Guo et al. 2016, Yahya et al. 2018). DMSO is capable of disrupting biofilm and acts as a synergistic agent in conjunction with some antibiotics (Yahya et al. 2018). For these reasons, DMSO may be considered a useful tool in the treatment of PBIE although there are no peer-reviewed reports which evaluate DMSO for this purpose. Furthermore, some reports have shown that DMSO can inhibit the bacteriocidal activity of ampicillin, kanamycin and some quinolones (Mi et al. 2016). Systemic side effects of DMSO have been documented in mice and must be considered for both the horse and the veterinarian (Guo et al. 2016).

\section{$\mathrm{N}$-acetylcysteine}

$\mathrm{N}$-acetylcysteine is a powerful antioxidant, a precursor of L-cysteine and it also has mucolytic properties (Mokhtari et al. 2017). These characteristics make it a useful adjunctive treatment in bacterial or fungal endometritis. $\mathrm{N}$-acetylcysteine (3.3\% solution) decreased biofilm biomass and killed $E$. coli isolates but it was not as effective against $P$. aeruginosa or $K$. pneumoniae isolates (Ferris et al. 2016). In addition, $\mathrm{N}$-acetylcysteine has anti-inflammatory properties which modulate the endometrial response (Melkus et al. 2013).

\section{Hydrogen peroxide}

Hydrogen peroxide is a by-product of metabolic processes. It is an acidic, water-soluble fluid with strong oxidative properties and has the ability to inhibit many enzymatic processes. Hydrogen peroxide produces oxidants such as singlet oxygen, superoxide radicals and a hydroxyl radical which can be cytotoxic at high levels. These properties may be exploited clinically and exposure to $1 \%$ hydrogen peroxide decreased biofilm biomass and reduced CFU of E. coli and K. pneumoniae isolates from horses (Ferris et al. 2016).

Hydrogen peroxide inhibits the growth of $E$. coli by inducing the formation of highly toxic hydroxyl radicals. However, it is not the panacea for infectious endometritis treatment. Bacteria like E. coli and 
Staphylococci are 'catalase positive', that is, they utilise the enzyme, catalase, to break down hydrogen peroxide into hydrogen and water to protect themselves from cytotoxicity (Serra et al. 2008). Furthermore, E. coli is capable of adaptation and undergoing DNA repair in response to exposure to hydrogen peroxide and, therefore, there is the potential for mutation and the development of resistance (Min \& Gu 2003). In vitro evaluation of hydrogen peroxide treatment has also revealed its ability to induce breakages in dsDNA and drive phenotypic diversity in yeasts (Qi et al. 2019) suggesting the potential for resistance to develop.

Generally, catalase-negative bacteria such as Streptococci, Enterococcus spp. and Clostridia spp. are susceptible to hydrogen peroxide. Other bacteria, like some Streptococci, are 'catalase negative' but actually produce hydrogen peroxide to protect their population (Serra et al. 2008). In healthy women, hydrogen peroxide producing Lactobacillus spp. predominate in the vaginal flora (Martin et al. 2012) which may be a reflection of the role of balance in natural immune systems in maintaining a healthy microbiome (Heil et al. 2018).

\section{Tris-EDTA}

Metal chelating agents such as Tris-EDTA may be useful for disrupting biofilm-forming agents, such as $P$. aeruginosa (Banin et al. 2006) or fungal infections (Lyle et al. 2011). However, their clinical efficacy is yet to be proven in controlled studies in vivo. Banin et al. (2006) explain that Tris-EDTA chelates divalent metal cations from their binding sites in lipopolysaccharide membranes to result in detachment, lysis and killing of cells. In vitro studies have reported a beneficial effect of Tris-EDTA as a potentiator of aminoglycoside activity against human strains of Staphylococcus aureus, Enterococcus faecalis, $P$. aeruginosa and Enterobacteriaceae spp. (Lebeaux et al. 2015). Banin et al. (2006) confirmed that TrisEDTA in combination with gentamicin was the most effective disperser of biofilm cells, thereby effectively exposing bacteria to intense antimicrobial activity. Early studies in bovine endometritis demonstrated that Tris-EDTA may reverse antimicrobial resistance to some antibiotics (oxytetracycline, enrofloxacin, lincomycin-spectinomycin or amikacin) and produce good pregnancy rates after treatment (Farca et al. 1997). The infusion of Tris-EDTA (250 mM EDTA and $50 \mathrm{mM}$ Tris, $\mathrm{pH}$ 8) into the mare's uterus has been considered a useful adjunct to antimicrobial treatment for endometritis caused by Pseudomonas spp. It is safe to use in the uterus-producing a mild inflammation that resolves within 7 days of treatment in a similar manner to saline infusion (Youngquist et al. 1984). Recently, in vitro studies of biofilm produced by equine uterine pathogens observed that Tris-EDTA was able to reduce biofilm mass by $10-40 \%$ (Ferris et al. 2016).

\section{Kerosene}

In New Zealand, kerosene is used as an intrauterine treatment to purge the uterine lymphatic glands during chronic bacterial endometritis. Treatment of the uterus with kerosene strips away mucus, cilia and, in some cases, endometrial epithelial cells and stimulates the apical portions of the endometrial glands (Bracher et al. 1991). This allows regeneration of the epithelium and mucociliary apparatus (LeBlanc \& Causey 2009, Bradecamp et al. 2014). Inflammatory changes in the uterus resolve sufficiently within 21 days of treatment, so that $50 \%$ of treated mares conceived and carried a foal to term despite their predicted foaling rate being $<50 \%$ based on their uterine biopsy scores (Bracher et al. 1991).

\section{Treatment of fungal endometritis}

Therapy for fungal endometritis is directed towards correcting a combination of predisposing factors such as uterine infusions with non-antibiotic agents, uterine lavage and systemic and/or intrauterine administration of anti-fungal agents (Stout 2008, Dasciano 2009). It may also be beneficial to apply topical antifungal medication to the vagina and clitoris as these areas may act as a reservoir or nidus for reinfection (Stout 2008). Prior to treatment it is beneficial to remove inflammatory uterine fluid by lavage with sterile saline or lactated Ringer's solution. Non-specific treatments are also often utilised to kill fungal organisms and/or disrupt biofilm. Those may include N-Acetylcysteine solution, DMSO, hydrogen peroxide, povidone-iodine, Tris-EDTA and acetic acid or vinegar.

Once diagnosed, yeasts and hyphate fungi are often susceptible to polyene class antifungal agents such as nystatin and amphotericin B, but their susceptibility to azole class antifungal agents such as ketoconazole, fluconazole, and miconazole may vary (Beltaire et al. 2012). Several anti-fungal agents are available for intrauterine therapy or systemic therapy. Fluconazole and itraconazole are available as oral formulations which can provide long term anti-mycotic activity and may be an important component of a multimodal treatment programme for fungal endometritis in the mare (Scofield et al. 2013). Treatment with more than one anti-fungal agent may be indicated in refractory or recurrent clinical cases. One recommended therapeutic protocol involves uterine lavage followed by intrauterine infusion of an antifungal agent (nystatin) once daily for five days and concurrent systemic administration of a second antifungal agent (fluconazole) for 21 days (McCue \& Ferris 2018). Mixing an antifungal agent such as nystatin into a buffered chelator such as Tris-EDTA prior to uterine infusion may potentiate the effect of the antifungal agent. Lufenuron (Program, Novartis Animal Health) is an anti-flea treatment that inhibits chitin 
synthesis in the cell wall. It has been reported to be effective to treat equine fungal endometritis if the fungal agent has chitin in its cell walls (Hess et al. 2002).

\section{Conclusion}

After breeding, all mares will experience some degree of physiological endometritis, which involves a mechanical and immunological response used by the mare to evacuate excess fluid, contaminants and dead spermatozoa, and ultimately creates a hospitable environment for embryo development. The challenge is to preserve and facilitate the balance between the complex pro- and anti-inflammatory uterine responses to the allogenic spermatozoa to ensure the uterine environment is hospitable at the time of arrival of the embryo 6 days after ovulation. This balance can be attained by careful management involving hygiene, exploiting the oestrogenic and immunologically primed uterus at the time of breeding, and minimising unnecessary invasion of the reproductive tract and application of treatments that may not be indicated. Blanket treatment with antibiotics is no longer a suitable strategy and needs to be evidence-based. An increased interest in non-antibiotic alternatives warrants further investigation, but more data is required to evaluate their efficacy and safety. It is also possible that resistance could develop to these alternative treatments and beware of their potential to actually induce mutations in some bacteria. New diagnostic methods that identify the genes involved in a mare's predisposition to endometritis, combined with the application of new immunological treatments, will help us address the prevention of PBIE and its detrimental consequences on fertility in the mare.

\section{Declaration of interest}

The authors declare that there is no conflict of interest that could be perceived as prejudicing the impartiality of this review.

\section{Funding}

This research did not receive any specific grant from any funding agency in the public, commercial or not-for-profit sector.

\section{Author contribution statement}

$\mathrm{L} M$ conceived and coordinated the paper and wrote the sections on diagnostics, treatments, Figures 1 and 2 and non-antibiotic therapies. P M wrote the section on fungal endometritis and provided Figure 3 and provided review of the content. C A wrote the section on pathophysiology of endometritis and contributed to reference sourcing and provided review of the content.

\section{References}

Albihn A, Baverud V \& Magnusson U 2003 Uterine microbiology and antimicrobial susceptibility in isolated bacteria from mares with fertility problems. Acta Veterinaria Scandinavica 44 121-129. (https://doi. org/10.1186/1751-0147-44-121)

Alghamdi AS, Foster DN, Carlson CS \& Troedsson MH 2005 Nitric oxide levels and nitric oxide synthase expression in uterine samples from mares susceptible and resistant to persistent breeding-induced endometritis. American Journal of Reproductive Immunology 53 230-237. (https://doi. org/10.1111/j.1600-0897.2005.00270.x)

Allen WR, Brown L, Wright M \& Wilsher S 2007 Reproductive efficiency of flatrace and national hunt thoroughbred mares and stallions in England. Equine Veterinary Journal 39 438-445. (https://doi.org/10.2746/042516 $407 \times 1737581)$

Allen JL, Begg AP \& Browning GF 2011 Outbreak of equine endometritis caused by a genotypically identical strain of Pseudomonas aeruginosa. Journal of Veterinary Diagnostic Investigation 23 1236-1239. (https:// doi.org/10.1177/1040638711425589)

Annandale A, Stroehle RM, Schulman ML, Sibeko-Matjila KP, Fosgate GT, Handler J, Vemming DC \& Clift SJ 2018 Influence of cycle stage, age and endometrial biopsy score on oxytocin receptor distribution and gene expression in the cervix and uterus of non-pregnant mares. Theriogenology 120 1-9. (https://doi.org/10.1016/j.theriogenology. 2018.07.013)

Asbury AC \& Hansen PJ 1987 Effects of susceptibility of mares to endometritis and stage of cycle on phagocytic activity of uterine-derived neutrophils. Journal of Reproduction and Fertility: Supplement 35 311-316.

Banin E, Brady KM \& Greenberg EP 2006 Chelator-induced dispersal and killing of Pseudomonas aeruginosa cells in a biofilm. Applied and Environmental Microbiology 72 2064-2069. (https://doi.org/10.1128/AE M.72.3.2064-2069.2006)

Beehan DP, Wolfsdorf K, Elam J, Krekeler N, Paccamonti D \& Lyle SK 2015 The evaluation of biofilm-forming potential of Escherichia coli collected from the equine female reproductive tract. Journal of Equine Veterinary Science 35 935-939. (https://doi.org/10.1016/j. jevs.2015.08.018)

Beltaire KA, Cheong SH \& Coutinho Da Silva MA 2012 Retrospective study on equine uterine fungal isolates and antifungal susceptibility patterns (1999-2011). Equine Veterinary Journal: Supplement 44 84-87. (https:// doi.org/10.1111/j.2042-3306.2012.00608.x)

Blanchard TL, Kenney RM \& Timoney PJ 1992 Venereal disease. Veterinary Clinics of North America: Equine Practice 8 191-203. (https://doi. org/10.1016/s0749-0739(17)30475-3)

Blue MG 1987 Mycotic endometritis in mares. Review and clinical observations. New Zealand Veterinary Journal 35 181-183. (https://doi. org/10.1080/00480169./1987.35439)

Bracher V, Neuschaefer A \& Allen WR 1991 The effect of intrauterine infusion of kerosene on the endometrium of mares. Journal of Reproduction and Fertility: Supplement 44 706-707.

Bradecamp EA, Ahlschwede SA \& Cook JL 2014 The effects of intrauterine kerosene infusion on endometrial epithelial cilia concentration. Journal of Equine Veterinary Science 34 134. (https://doi.org/10.1016/j. jevs.2013.10.092)

Brinsko SP, Varner DD, Blanchard TL \& Meyers SA 1990 The effect of postbreeding uterine lavage on pregnancy rate in mares. Theriogenology 33 465-475. (https://doi.org/10.1016/0093-691x(90)90504-m)

Brinsko SP, Varner DD \& Blanchard TL 1991 The effect of uterine lavage performed four hours post insemination on pregnancy rate in mares. Theriogenology 35 1111-1119. (https://doi.org/10.1016/0093691X(91)90358-K)

Brinkso SP, Rigby S, Varner DD \& Blanchard TL 2003 A Practical Method for Recognizing Mares Susceptible to Post Breeding Endometritis, pp. 363-365. Proceedings of the American Association of Equine Practitioners.

Brock MT, Fedderly GC, Borlee GI, Russell MM, Filipowska LK, Hyatt DR, Ferris RA \& Borlee BR 2017 Pseudomonas aeruginosa variants obtained from veterinary clinical samples reveal a role for cyclic diGMP in biofilm formation and colony morphology. Microbiology 163 1613-1625. (https://doi.org/10.1099/mic.0.000541)

Bucca S, Carli A, Buckley T, Dolci G \& Fogarty U 2008 The use of dexamethasone administered to mares at breeding time in the 
modulation of persistent mating induced endometritis. Theriogenology 70 1093-1100. (https://doi.org/10.1016/j.theriogenology.2008.06.029)

Cadario ME, Thatcher MJD \& Leblanc MM 1995 Relationship between prostaglandin and uterine clearance of radiocolloid in the mare. Biology of Reproduction Monograph Series 1495-500.

Campbell ML \& England GC 2004 Effect of teasing, mechanical stimulation and the intrauterine infusion of saline on uterine contractions in mares. Veterinary Record 155 103-110. (https://doi.org/10.1136/vr.155.4.103)

Canisso IF, Stewart J \& Coutinho Da Silva MA 2016 Endometritis: managing persistent post-breeding endometritis. Veterinary Clinics of North America: Equine Practice 32 465-480. (https://doi.org/10.1016/j. cveq.2016.08.004)

Canisso IF, Segabinazzi LGTM \& Fedorka CE 2020 Persistent breedinginduced endometritis in mares - a multifaceted challenge: from clinical aspects to immunopathogenesis and pathobiology. International Journal of Molecular Sciences 21 1432. (https://doi.org/10.3390/ijms21041432)

Casagrande Proietti P, Bietta A, Coppola G, Felicetti M, Cook RF, Coletti M, Marenzoni ML \& Passamonti F 2011 Isolation and characterization of beta-haemolytic-Streptococci from endometritis in mares. Veterinary Microbiology 152 126-130. (https://doi.org/10.1016/j. vetmic.2011.04.009)

Caslick E 1937 The vulva and the vulvo-vaginal orifice and its relation to genital health of the thoroughbred mare. Cornell Veterinarian $\mathbf{2 7}$ $178-187$

Cazales N, Fiala-Rechsteiner SM, Cavestany D \& Mattos RC 2018 Insemination dose and site with frozen semen affects the sperm transport and inflammatory response in mares? Journal of Equine Veterinary Science 66 109-110. (https://doi.org/10.1016/j.jevs.2018.05.155)

Christoffersen M \& Troedsson M 2017 Inflammation and fertility in the mare. Reproduction in Domestic Animals 52 (Supplement 3) 14-20. (https://doi.org/10.1111/rda.13013)

Christoffersen M, Woodward E, Bojesen AM, Jacobsen S, Petersen MR, Troedsson MHT \& Lehn-Jensen H 2012 Inflammatory responses to induced infectious endometritis in mares resistant or susceptible to persistent endometritis. BMC Veterinary Research 8 41-41. (https://doi. org/10.1186/1746-6148-8-41)

Christoffersen M, Brandis L, Samuelsson J, Bojesen AM, Troedsson MHT \& Petersen MR 2015a Diagnostic double-guarded low-volume uterine lavage in mares. Theriogenology 83 222-227. (https://doi.org/10.1016/j. theriogenology.2014.09.008)

Christoffersen M, Soderlind M, Rudefalk SR, Pedersen HG, Allen J \& Krekeler N 2015b Risk factors associated with uterine fluid after breeding caused by Streptococcus zooepidemicus. Theriogenology $\mathbf{8 4}$ 1283-1290. (https://doi.org/10.1016/j.theriogenology.2015.07.007)

Combs GB, Leblanc MM, Neuwirth L \& Tran TQ 1996 Effects of prostaglandin F2 $\alpha$, cloprostenol and fenprostalene on uterine clearance of radiocolloid in the mare. Theriogenology 45 1449-1455. (https://doi. org/10.1016/0093-691X(96)00112-4)

Costerton JW, Stewart PS \& Greenberg EP 1999 Bacterial biofilms: a common cause of persistent infections. Science 284 1318-1322. (https:// doi.org/10.1126/science.284.5418.1318)

Coutinho Da Silva MA \& Alvarenga MA 2011 Fungal endometritis. In Equine Reproduction. Eds AO Mckinnon, EL Squires, W Vaala \& DD Varner. Danvers, Mass: Wiley-Blackwell Publishing.

Coutinho Da Silva MA, Darr CR, Moraes LE \& Forshey BS 2017 Lactoferrin modulates uterine inflammation postbreeding in the mare. Journal of Equine Veterinary Science 56 63-67. (https://doi.org/10.1016/j. jevs.2017.05.007)

Dasciano JD 2009 How and when to treat endometritis with systemic or local antibiotics. Clinical Theriogenology $1411-432$.

Dascanio JJ, Schweizer C \& Ley WB 2001 Equine fungal endometritis. Equine Veterinary Education 13 324-329. (https://doi.org/10.1111/j. 2042-3292.2001.tb00122.x)

Davis HA, Stanton MB, Thungrat K \& Boothe DM 2013 Uterine bacterial isolates from mares and their resistance to antimicrobials: 8,296 cases (2003-2008). Journal of the American Veterinary Medical Association 242 977-983. (https://doi.org/10.2460/javma.242.7.977)

Davolli GM, Beavers KN, Medina V, Sones JL, Pinto CRF, Paccamonti DL \& Causey RC 2018 Concentrations of sulfadiazine and trimethoprim in blood and endometrium of mares after administration of an oral suspension. Journal of Equine Veterinary Science 67 27-30. (https://doi. org/10.1016/j.jevs.2018.02.022)
Dell'aqua JA, Papa FO, Lopes MD, Alvarenga MA, Macedo LP \& Melo CM 2006 Modulation of acute uterine inflammatory response after artificial insemination with equine frozen semen. Animal Reproduction Science 94 270-273. (https://doi.org/10.1016/j.anireprosci.2006.03.061)

Doty A, Buhi WC, Benson S, Scoggin KE, Pozor M, Macpherson M, Mutz M \& Troedsson MH 2011 Equine CRISP3 modulates interaction between spermatozoa and polymorphonuclear neutrophils. Biology of Reproduction 85 157-164. (https://doi.org/10.1095/ biolreprod.110.084491)

Evans MJ, Hamer JM, Gason LM \& Irvine CH 1987 Factors affecting uterine clearance of inoculated materials in mares. Journal of Reproduction and Fertility: Supplement 35 327-334.

Ezz MA, Marey MA, Elweza AE, Kawai T, Heppelmann M, Pfarrer C, Balboula AZ, Montaser A, Imakawa K, Zaabel SM et al. 2019 TLR2/4 signaling pathway mediates sperm-induced inflammation in bovine endometrial epithelial cells in vitro. PLOS ONE 14 e0214516. (https:// doi.org/10.1371/journal.pone.0214516)

Farca AM, Nebbia P, Robino P \& Re G 1997 Effects of the combination antibiotic-EDTA-Tris in the treatment of chronic bovine endometritis caused by antimicrobial-resistant bacteria. Pharmacological Research 36 35-39. (https://doi.org/10.1006/phrs.1997.0199)

Fedorka CE, Scoggin KE, Woodward EM, Squires EL, Ball BA \& Troedsson M 2017 The effect of select seminal plasma proteins on endometrial mRNA cytokine expression in mares susceptible to persistent mating-induced endometritis. Reproduction in Domestic Animals 52 89-96. (https://doi. org/10.1111/rda.12813)

Fedorka CE, Scoggin KE, Boakari YL, Hoppe NE, Squires EL, Ball BA \& Troedsson MHT 2018 The anti-inflammatory effect of exogenous lactoferrin on breeding-induced endometritis when administered postbreeding in susceptible mares. Theriogenology 114 63-69. (https://doi. org/10.1016/j.theriogenology.2018.03.017)

Ferris RA 2017 Current understanding of bacterial biofilms and latent infections: a clinical perspective. Revista Brasileira de Reproducao Animal 41 74-80.

Ferris RA, Dern K, Veir JK, Hawley JR, Lappin MR \& Mccue PM 2013 Development of a broad-range quantitative polymerase chain reaction assay to detect and identify fungal DNA in equine endometrial samples. American Journal of Veterinary Research 74 161-165. (https://doi. org/10.2460/ajvr.74.1.161)

Ferris RA, Frisbie DD \& Mccue PM 2014a Use of mesenchymal stem cells or autologous conditioned serum to modulate the inflammatory response to spermatozoa in mares. Theriogenology 82 36-42. (https:// doi.org/10.1016/j.theriogenology.2014.02.015)

Ferris RA, Wittstock SM, Mccue PM \& Borlee BR 2014b Evaluation of biofilms in gram-negative bacteria isolated from the equine uterus. Journal of Equine Veterinary Science 34 121. (https://doi.org/10.1016/j. jevs.2013.10.082)

Ferris RA, Mccue PM, Borlee GI, Loncar KD, Hennet ML \& Borlee BR 2016 In vitro efficacy of nonantibiotic treatments on biofilm disruption of Gram-negative pathogens and an in vivo model of infectious endometritis utilizing isolates from the equine uterus. Journal of Clinical Microbiology 54 631-639. (https://doi.org/10.1128/JCM.02861-15)

Ferris RA, Mccue PM, Borlee GI, Glapa KE, Martin KH, Mangalea MR, Hennet ML, Wolfe LM, Broeckling CD \& Borlee BR 2017 Model of chronic equine endometritis involving a Pseudomonas aeruginosa biofilm. Infection and Immunity 85. (https://doi.org/10.1128/IAI.0033217)

Fiala SM, Pimentel CA, Mattos AL, Gregory RM \& Mattos RC 2007 Effect of sperm numbers and concentration on sperm transport and uterine inflammatory response in the mare. Theriogenology 67 556-562. (https://doi.org/10.1016/j.theriogenology.2006.09.005)

Friso AM, Segabinazzi LGTM, Cyrino $M$, Correal SB, Freitas-Dell'Aqua CP, Teoro do Carmo M, Dell'Aqua JA, Miró J, Papa FO \& Alvarenga MA 2019 Periovulatory administration of firocoxib did not alter ovulation rates and mitigated post-breeding inflammatory response in mares. Theriogenology 138 24-30. (https://doi.org/10.1016/j.theriogenology. 2019.06.045)

Fu Q, Wei Z, Chen Y, Xiao P, Lu Z \& Liu X 2013 Identification of a surface protective antigen, CSP of Streptococcus equi ssp. zooepidemicus. Vaccine 31 1400-1405. (https://doi.org/10.1016/j.vaccine.2012.12.079)

Fumuso EA, Aguilar J, Giguere S, Rivulgo M, Wade J \& Rogan D 2007 Immune parameters in mares resistant and susceptible to persistent 
post-breeding endometritis: effects of immunomodulation. Veterinary Immunology and Immunopathology $118 \quad 30-39 . \quad$ (https://doi. org/10.1016/j.vetimm.2007.04.009)

Fumuso E, Carmo MT, Herrera MF, Cantatore SE, Landim FC, Lombardo D, Felipe AE, Rosatti JJ, Redolatti C \& Alvarenga MA 2014 Smooth muscle actin and collagen immunohistochemical evaluation in the endometrium of mares treated with bone marrow stem cells. Journal of Equine Veterinary Science 34 155. (https://doi.org/10.1016/j. jevs.2013.10.109)

Gallacher K, Woolford L, Santos LC \& Kind KL 2018 Real-time-in vivo microscopic imaging of equine endometrium using confocal laser endomicroscopy: preliminary observations and feasibility study. Journal of Equine Veterinary Science 66 106-107. (https://doi.org/10.1016/j. jevs.2018.05.153)

Gores-Lindholm AR, Leblanc MM, Causey R, Hitchborn A, FayrerHosken RA, Kruger M, Vandenplas ML, Flores P \& Ahlschwede S 2013 Relationships between intrauterine infusion of $\mathrm{N}$-acetylcysteine, equine endometrial pathology, neutrophil function, post-breeding therapy, and reproductive performance. Theriogenology 80 218-227. (https://doi.org/ 10.1016/j.theriogenology.2013.03.026)

Guo Q, Wu Q, Bai D, Liu Y, Chen L, Jin S, Wu Y \& Duan K 2016 Potential use of dimethyl sulfoxide in treatment of infections caused by Pseudomonas aeruginosa. Antimicrobial Agents and Chemotherapy 60 7159-7169. (https://doi.org/10.1128/AAC.01357-16)

Hanlon DW, Stevenson M, Evans MJ \& Firth EC 2012 Reproductive performance of Thoroughbred mares in the Waikato region of New Zealand: 2. Multivariable analyses and sources of variation at the mare, stallion and stud farm level. New Zealand Veterinary Journal 60 335-343. (https://doi.org/10.1080/00480169.2012.696240)

Heil BA, Thompson SK, Kearns TA, Davolli GM, King G \& Sones JL 2018 Metagenetic characterization of the resident equine uterine microbiome using multiple techniques. Journal of Equine Veterinary Science 66111. (https://doi.org/10.1016/j.jevs.2018.05.156)

Heil BA, Paccamonti DL \& Sones JL 2019 Role for the mammalian female reproductive tract microbiome in pregnancy outcomes. Physiological Genomics 51 390-399. (https://doi.org/10.1152/physiolgenomics.0 0045.2019)

Hess MB, Parker NA, Purswell BJ \& Dascanio JD 2002 Use of lufenuron as a treatment for fungal endometritis in four mares. Journal of the American Veterinary Medical Association 221 266-7, 240. (https://doi. org/10.2460/javma.2002.221.266)

Huber D, Amsler E, Vidondo B, Kaeser R, Wespi B, Sieme H \& Burger D 2019 Increase of pregnancy rate after multiple periovulatory inseminations in mares. Tierarztl Prax Ausg G Grosstiere Nutztiere 47 18-24. (https://doi.org/10.1055/a-0803-1211)

Hughes JP \& Loy RG 1969 Investigations on the effect on intrauterine inoculation of Streptococcus zooepidemicus in the mare. Proceedings of the American Association of Equine Practioners 15 289-292.

Jacob SW \& Herschler R 1983 Dimethyl sulfoxide AFTER twenty years. Annals of the New York Academy of Sciences 411 xiii-xvii. (https://doi. org/10.1111/j.1749-6632.1983.tb47276.x)

Kalpokas I, Perdigón F, Rivero R, Talmon M, Sartore I \& Viñoles C 2010 Effect of a povidone-iodine intrauterine infusion on progesterone levels and endometrial steroid receptor expression in mares. Acta Veterinaria Scandinavica 52 66. (https://doi.org/10.1186/1751-0147-52-66)

Katila T 1995 Onset and duration of uterine inflammatory response of mares after insemination with fresh semen. Biology of Reproduction 52515 517. (https://doi.org/10.1093/biolreprod/52.monograph_series1.515)

Katila T 2012 Post-mating inflammatory responses of the uterus. Reproduction in Domestic Animals 47 (Supplement 5) 31-41. (https:// doi.org/10.1111/j.1439-0531.2012.02120.x)

Katila T 2016 Evaluation of diagnostic methods in equine endometritis. Reproductive Biology 16 189-196. (https://doi.org/10.1016/j. repbio.2016.06.002)

Khan FA, Chenier TS, Murrant CL, Foster RA, Hewson J \& Scholtz EL 2017 Dose-dependent inhibition of uterine contractility by nitric oxide: a potential mechanism underlying persistent breeding-induced endometritis in the mare. Theriogenology 90 59-64. (https://doi.org/ 10.1016/j.theriogenology.2016.11.026)

Kidd TJ, Gibson JS, Moss S, Greer RM, Cobbold RN, Wright JD, Ramsay KA, Grimwood K \& Bell SC 2011 Clonal complex Pseudomonas aeruginosa in horses. Veterinary Microbiology 149 508-512. (https://doi. org/10.1016/j.vetmic.2010.11.030)
Koo H, Allan RN, Howlin RP, Stoodley P \& Hall-Stoodley L 2017 Targeting microbial biofilms: current and prospective therapeutic strategies. Nature Reviews: Microbiology 15 740-755. (https://doi.org/10.1038/ nrmicro.2017.99)

Kotilainen T, Huhtinen M \& Katila T 1994 Sperm-induced leukocytosis in the equine uterus. Theriogenology 41 629-636. (https://doi. org/10.1016/0093-691x(94)90173-g)

Lebeaux D, Leflon-Guibout V, Ghigo JM \& Beloin C 2015 In vitro activity of gentamicin, vancomycin or amikacin combined with EDTA or I-arginine as lock therapy against a wide spectrum of biofilm-forming clinical strains isolated from catheter-related infections. Journal of Antimicrobial Chemotherapy 70 1704-1712. (https://doi.org/10.1093/jac/dkv044)

Leblanc MM 2009 The current status of antibiotic use in equine reproduction. Equine Veterinary Education 21 156-167. (https://doi.org/ 10.2746/095777308X357621)

Leblanc MM 2010 Advances in the diagnosis and treatment of chronic infectious and post-mating-induced endometritis in the mare. Reproduction in Domestic Animals 45 (Supplement 2) 21-27. (https:// doi.org/10.1111/j.1439-0531.2010.01634.x)

Leblanc MM \& Causey RC 2009 Clinical and subclinical endometritis in the mare: both threats to fertility. Reproduction in Domestic Animals 44 (Supplement 3) 10-22. (https://doi.org/10.1111/j.1439-0531.2009. 01485.x)

Leblanc MM, Asbury AC \& Lyle SK 1989 Uterine clearance mechanisms during the early postovulatory period in mares. American Journal of Veterinary Research 50 864-867.

Leblanc M, Neuwirth L, Mauragis D, Klapstein E \& Tran T 1994a Oxytocin enhances clearance of radiocolloid from the uterine lumen of reproductively normal mares and mares susceptible to endometritis. Equine Veterinary Journal 26 279-282. (https://doi.org/10.1111/j.20423306.1994.tb04387.x)

Leblanc MM, Neuwirth L, Asbury AC, Tran T, Mauragis D \& Klapstein E $1994 b$ Scintigraphic measurement of uterine clearance in normal mares and mares with recurrent endometritis. Equine Veterinary Journal 26 109-113. (https://doi.org/10.1111/j.2042-3306.1994.tb04346.x)

Leblanc MM, Johnson RD, Calderwood-Mays MB \& Valderrama C 1995 Lymphatic clearance of india ink in reproductively normal mares and mares susceptible to endometritis. Biology of Reproduction Monograph Series 1 109-113.

Liu IK \& Troedsson MH 2008 The diagnosis and treatment of endometritis in the mare: yesterday and today. Theriogenology 70 415-420. (https:// doi.org/10.1016/j.theriogenology.2008.05.040)

Loncar KD, Ferris RA, Mccue PM, Borlee GI, Hennet ML \& Borlee BR 2017 In vitro biofilm disruption and bacterial killing using nonantibiotic compounds Against Gram-negative equine uterine pathogens. Journal of Equine Veterinary Science 53 94-99. (https://doi.org/10.1016/j. jevs.2017.02.003)

Lyle S, Leblanc MM, Staempfli SA, Beehan D \& Morgan T 2011 How to use a buffered chelator solution for mares with chronic endometritis Proceedings of the American Association of Equine Practioners 57 16-18.

Mah TF \& O'Toole GA 2001 Mechanisms of biofilm resistance to antimicrobial agents. Trends in Microbiology 9 34-39. (https://doi. org/10.1016/s0966-842x(00)01913-2)

Marth CD, Firestone SM, Hanlon D, Glenton LY, Browning GF, Young ND \& Krekeler N 2018a Innate immune genes in persistent mating-induced endometritis in horses. Reproduction, Fertility, and Development 30 533-545. (https://doi.org/10.1071/RD17157)

Marth CD, Macolino GP \& Krekeler N 2018b The value of innate immune genes as diagnostic markers for endometritis in mares. Journal of Equine Veterinary Science 66 112. (https://doi.org/10.1016/j.jevs.2018.05.157)

Martin DH, Zozaya M, Lillis R, Miller J \& Ferris MJ 2012 The microbiota of the human genitourinary tract: trying to see the forest through the trees. Transactions of the American Clinical and Climatological Association $123242-256$.

Mccue P \& Ferris RA 2018 Formulary and Protocols in Equine Reproduction. Colorado State University.

Melkus E, Witte T, Walter I, Heuwieser W \& Aurich C 2013 Investigations on the endometrial response to intrauterine administration of $\mathrm{N}$-acetylcysteine in oestrous mares. Reproduction in Domestic Animals 48 591-597. (https://doi.org/10.1111/rda.12131)

Metcalf ES 2014 The effect of platelet rich plasma (PRP) on intraluminal fluid and pregnancy rates in mares susceptible to persistent mating 
induced endometritis (PMIE). Journal of Equine Veterinary Science 34 128. (https://doi.org/10.1016/j.jevs.2013.10.087)

Mi H, Wang D, Xue Y, Zhang Z, Niu J, Hong Y, Drlica K \& Zhao X 2016 Dimethyl sulfoxide protects Escherichia coli from rapid antimicrobialmediated killing. Antimicrobial Agents and Chemotherapy 60 5054-5058. (https://doi.org/10.1128/AAC.03003-15)

Min J \& Gu MB 2003 Acclimation and repair of DNA damage in recombinant bioluminescent Escherichia coli. Journal of Applied Microbiology 95 479-483. (https://doi.org/10.1046/j.1365-2672.2003. 02001.x)

Mitchell AR, Diel De Amorim M, Thachil AJ, Altier C \& Cheong SH 2018 Uterine bacterial isolates from mares and their resistance to antimicrobials. Journal of Equine Veterinary Science 66 114. (https://doi. org/10.1016/j.jevs.2018.05.159)

Mokhtari V, Afsharian P, Shahhoseini M, Kalantar SM \& Moini A 2017 A review on various uses of $\mathrm{N}$-acetyl cysteine. Cell Journal 19 11-17. (https://doi.org/10.22074/cellj.2016.4872)

Morris LH \& Allen WR 2002 Reproductive efficiency of intensively managed Thoroughbred mares in Newmarket. Equine Veterinary Journal 34 51-60. (https://doi.org/10.2746/042516402776181222)

Nath LC, Anderson GA \& Mckinnon AO 2010 Reproductive efficiency of Thoroughbred and Standardbred horses in north-east Victoria. Australian Veterinary Journal 88 169-175. (https://doi.org/10.1111/j.1751-0813. 2010.00565.x)

Olsen I 2015 Biofilm-specific antibiotic tolerance and resistance. European Journal of Clinical Microbiology and Infectious Diseases 34 877-886. (https://doi.org/10.1007/s10096-015-2323-z)

Olsen LM, Al-Bagdadi FK, Richardson GF, Archbald LF, Braun WF, Mccoy DJ, Godke RA, Titkemeyer CW \& Thompson DL 1992 A histological study of the effect of saline and povidone-iodine infusions on the equine endometrium. Theriogenology 37 1311-1325. (https:// doi.org/10.1016/0093-691X(92)90186-U)

Petersen MR, Møller Nielsen J, Lehn-Jensen H \& Bojesen AM 2009 Streptococcus equi subspecies zooepidemicus resides deep in the chronically infected endometrium of mares. Clinical Theriogenology 2009 393-409.

Petersen MR, Skive B, Christoffersen M, Lu K, Nielsen JM, Troedsson MH \& Bojesen AM 2015 Activation of persistent Streptococcus equi subspecies zooepidemicus in mares with subclinical endometritis. Veterinary Microbiology 179 119-125. (https://doi.org/10.1016/j. vetmic.2015.06.006)

Petersen MR, Rosenbrock A, Osborne M \& Bojesen AM 2018 High prevalence of subclinical endometritis in problem mares - effect of activation and treatment on fertility. Journal of Equine Veterinary Science 66 117. (https://doi.org/10.1016/j.jevs.2018.05.162)

Portus BJ, Reilas T \& Katila T 2005 Effect of seminal plasma on uterine inflammation, contractility and pregnancy rates in mares. Equine Veterinary Journal 37 515-519. (https://doi.org/10.2746/042516405775314844)

Pycock JF \& Allen WE 1990 Inflammatory components in uterine fluid from mares with experimentally induced bacterial endometritis. Equine Veterinary Journal 22 422-425. (https://doi.org/10.1111/j.2042-3306. 1990.tb04309.x)

Pycock JF \& Newcombe JR 1996 Assessment of the effect of three treatments to remove intrauterine fluid on pregnancy rate in the mare. Veterinary Record 138 320-323. (https://doi.org/10.1136/vr.138.14.320)

Qi L, Wu XC \& Zheng DQ 2019 Hydrogen peroxide, a potent inducer of global genomic instability. Current Genetics 65 913-917. (https://doi. org/10.1007/s00294-019-00969-9)

Quayle AJ 2002 The innate and early immune response to pathogen challenge in the female genital tract and the pivotal role of epithelial cells. Journal of Reproductive Immunology 57 61-79. (https://doi. org/10.1016/s0165-0378(02)00019-0)

Rasmussen CD, Haugaard MM, Petersen MR, Nielsen JM, Pedersen HG \& Bojesen AM 2013 Streptococcus equi subsp. zooepidemicus isolates from equine infectious endometritis belong to a distinct genetic group. Veterinary Research 44 26. (https://doi.org/10.1186/1297-9716-44-26)

Rebordao MR, Carneiro C, Alexandre-Pires G, Brito P, Pereira C, Nunes T, Galvao A, Leitao A, Vilela C \& Ferreira-Dias G 2014 Neutrophil extracellular traps formation by bacteria causing endometritis in the mare. Journal of Reproductive Immunology 106 41-49. (https://doi. org/10.1016/j.jri.2014.08.003)

Reghini MFS, Bussiere MCC, Ramires Neto C, Castro-Chaves MMB, Resende HL, Fioratti E, Farras MC \& Alvarenga MA 2014 Effect of the use of platelett rich plasma on post breeding uterine inflammatory response of mares. Journal of Equine Veterinary Science 34127.

Reghini MF, Ramires Neto C, Segabinazzi LG, Castro Chaves MM, Dell'Aqua Jr CPF, Bussiere MC, Papa FO \& Alvarenga MA 2016 Inflammatory response in chronic degenerative endometritis mares treated with platelet-rich plasma. Theriogenology 86 516-522.

Reilas T, Rivera Del Alamo MM, Liepina E, Yeste M \& Katila T 2016 Effects on the equine endometrium of cervical occlusion after insemination. Theriogenology 85 617-624. (https://doi.org/10.1016/j.theriogenology. 2015.09.053)

Riddle WT, Leblanc MM \& Stromberg AJ 2007 Relationships between uterine culture, cytology and pregnancy rates in a Thoroughbred practice. Theriogenology 68 395-402. (https://doi.org/10.1016/j.theri ogenology.2007.05.050)

Rigby SL, Barhoumi R, Burghardt RC, Colleran P, Thompson JA, Varner DD, Blanchard TL, Brinsko SP, Taylor T, Wilkerson MK et al. 2001 Mares with delayed uterine clearance have an intrinsic defect in myometrial function. Biology of Reproduction 65 740-747. (https://doi.org/10.1095/ biolreprod65.3.740)

Rink BE, Beyer T, French HM, Watson E, Aurich C \& Donadeu FX 2018 The fate of autologous endometrial mesenchymal stromal cells After application in the healthy equine uterus. Stem Cells and Development 27 1046-1052. (https://doi.org/10.1089/scd.2018.0056)

Risco AM, Reilas T, Muilu L, Kareskoski M \& Katila T 2009 Effect of oxytocin and flunixin meglumine on uterine response to insemination in mares. Theriogenology 72 1195-1201. (https://doi.org/10.1016/j.theri ogenology.2009.07.012)

Rojer H \& Aurich C 2010 Treatment of persistent mating-induced endometritis in mares with the non-steroid anti-inflammatory drug vedaprofen. Reproduction in Domestic Animals 45 e458-e460. (https:// doi.org/10.1111/j.1439-0531.2009.01572.x)

Rose BV, Firth M, Morris B, Roach JM, Wathes DC, Verheyen KLP \& De Mestre AM 2018 Descriptive study of current therapeutic practices, clinical reproductive findings and incidence of pregnancy loss in intensively managed thoroughbred mares. Animal Reproduction Science 188 74-84. (https://doi.org/10.1016/j.anireprosci.2017.11.011)

Sánchez-Rodríguez A, Gutiérrez-Cepeda L, Fernández-Novo A \& Serres C 2018 Evaluation of the effect of seminal plasma in the post insemination uterine inflammatory dynamic by power Doppler ultrasonography and low volume lavage in the mare. Journal of Equine Veterinary Science $\mathbf{6 6}$ 134. (https://doi.org/10.1016/j.jevs.2018.05.174)

Santos NC, Figueira-Coelho J, Martins-Silva J \& Saldanha C 2003 Multidisciplinary utilization of dimethyl sulfoxide: pharmacological, cellular, and molecular aspects. Biochemical Pharmacology 65 1035-1041. (https://doi.org/10.1016/s0006-2952(03)00002-9)

Schar MO, Diaz-Romero J, Kohl S, Zumstein MA \& Nesic D 2015 Plateletrich concentrates differentially release growth factors and induce cell migration in vitro. Clinical Orthopaedics and Related Research 473 1635-1643. (https://doi.org/10.1007/s11999-015-4192-2)

Schöniger S, Gräfe H \& Schoon HA 2017 Expression of toll-like receptors 2, 4 and 6 in different cell populations of the equine endometrium. Veterinary Immunology and Immunopathology 185 7-13. (https://doi. org/10.1016/j.vetimm.2017.01.002)

Schramme AR, Pinto CR, Davis J, Whisnant CS \& Whitacre MD 2008 Pharmacokinetics of carbetocin, a long-acting oxytocin analogue, following intravenous administration in horses. Equine Veterinary Journal 40 658-661. (https://doi.org/10.2746/042516408x334343)

Scofield DB, Wittenburg LA, Ferris RA, Gustafson DL \& Mccue PM 2013 Equine endometrial tissue concentration of fluconazole following oral administration. Journal of Equine Veterinary Science 33 44-50. (https:// doi.org/10.1016/j.jevs.2012.04.007)

Scofield D, Black J, Wittenburg L, Gustafson D, Ferris R, Hatzel J, TraubDargatz J \& Mccue P 2014 Endometrial tissue and blood plasma concentration of ceftiofur and metabolites following intramuscular administration of ceftiofur crystalline free acid to mares. Equine Veterinary Journal 46 606-610. (https://doi.org/10.1111/evj.12192)

Scott CJ 2019 A review of fungal endometritis in the mare. Equine Veterinary Education 32 444-448.

Serra B, Zhang J, Morales MD, Guzman-Vazquez De Prada A, Reviejo AJ \& Pingarron JM 2008 A rapid method for detection of catalase-positive and catalase-negative bacteria based on monitoring of hydrogen peroxide evolution at a composite peroxidase biosensor. Talanta 75 1134-1139. (https://doi.org/10.1016/j.talanta.2008.01.009) 
Sheldon IM, Rycroft AN, Dogan B, Craven M, Bromfield JJ, Chandler A, Roberts MH, Price SB, Gilbert RO \& Simpson KW 2010 Specific strains of Escherichia coli are pathogenic for the endometrium of cattle and cause pelvic inflammatory disease in cattle and mice. PLOS ONE 5 e9192. (https://doi.org/10.1371/journal.pone.0009192)

Sieme H, Bonk A, Hamann H, Klug E \& Katila T 2004 Effects of different artificial insemination techniques and sperm doses on fertility of normal mares and mares with abnormal reproductive history. Theriogenology 62 915-928. (https://doi.org/10.1016/j.theriogenology.2003.12.011)

Skarzynski DJ, Szóstek-Mioduchowska AZ, Rebordão MR, Jalali BM, Piotrowska-Tomala KK, Leciejewska N, Łazarczyk M \& FerreiraDias GM 2020 Neutrophils, monocytes and other immune components in the equine endometrium: friends or foes? Theriogenology 150150 157. (https://doi.org/10.1016/j.theriogenology.2020.01.018)

Skive B, Rohde M, Molinari G, Braunstein TH \& Bojesen AM 2017 Streptococcus equi subsp. zooepidemicus invades and survives in epithelial cells. Frontiers in Cellular and Infection Microbiology 7465. (https://doi.org/10.3389/fcimb.2017.00465)

Stewart PS \& Costerton JW 2001 Antibiotic resistance of bacteria in biofilms. Lancet 358 135-138. (https://doi.org/10.1016/s01406736(01)05321-1)

Stout TAE 2008 Fungal endometritis in the mare. Pferdeheilkunde Equine Medicine 24 83-87. (https://doi.org/10.21836/PEM20080117)

Thurlow LR, Hanke ML, Fritz T, Angle A, Aldrich A, Williams SH, Engebretsen IL, Bayles KW, Horswill AR \& Kielian T 2011 Staphylococcus aureus biofilms prevent macrophage phagocytosis and attenuate inflammation in vivo. Journal of Immunology 186 6585-6596. (https:// doi.org/10.4049/jimmunol.1002794)

Timoney JF 2004 The pathogenic equine streptococci. Veterinary Research 35 397-409. (https://doi.org/10.1051/vetres:2004025)

Troedsson MHT 1997 Therapeutic considerations for mating induced endometritis. Pferdeheilkunde Equine Medicine 13 516-520. (https:// doi.org/10.21836/PEM19970515)

Troedsson MHT 1999 Uterine clearance and resistance to persistent endometritis in the mare. Theriogenology 52 461-471. (https://doi. org/10.1016/S0093-691X(99)00143-0)

Troedsson MHT, Esteller-Vico A, Scoggin KE, Woodward EM, Squires EL, Ball BA \& Maxwell H 2014 Equine seminal plasma derived lactoferrin regulates binding of polymorphonuclear neutrophils (PMNs) to spermatozoa. Journal of Equine Veterinary Science 34 49. (https://doi. org/10.1016/j.jevs.2013.10.029)

Troedsson MHT \& Woodward EM 2016 Our current understanding of the pathophysiology of equine endometritis with an emphasis on breedinginduced endometritis. Reproductive Biology 16 8-12. (https://doi. org/10.1016/j.repbio.2016.01.003)

Vanderwall D K \& Woods G L 2003 Effect on fertility of uterine lavage performed immediately prior to insemination in mares. Journal of the American Veterinary Medical Association 222 1108-1110. (https://doi. org/10.2460/javma.2003.222.1108)

Voss JL, Wallace RA, Squires EL, Pickett BW \& Shideler RK 1979 Effects of synchronization and frequency in insemination on fertility. Journal of Reproduction and Fertility: Supplement 27 257-261.

Waelchli RO \& Winder NC 1987 Immunohistochemical evaluation of the equine endometrium during the oestrous cycle. Equine Veterinary Journal 19 299-302. (https://doi.org/10.1111/j.2042-3306.1987.tb014 15.x)

Walters MC, 3RD, Roe F, Bugnicourt A, Franklin MJ \& Stewart PS 2003 Contributions of antibiotic penetration, oxygen limitation, and low metabolic activity to tolerance of Pseudomonas aeruginosa biofilms to ciprofloxacin and tobramycin. Antimicrobial Agents and Chemotherapy 47 317-323. (https://doi.org/10.1128/aac.47.1.317-323.2003)

Watson ED 2000 Post-breeding endometritis in the mare. Animal Reproduction Science 60-61 221-232. (https://doi.org/10.1016/s03784320(00)00110-x)

Watson ED, Barbacini S, Berrocal B, Sheerin O, Marchi V, Zavaglia G \& Necchi D 2001 Effect of insemination time of frozen semen on incidence of uterine fluid in mares. Theriogenology 56 123-131. (https:// doi.org/10.1016/s0093-691x(01)00548-9)

Widders PR, Stokes CR, David JS \& Bourne FJ 1985 Immunohistological studies of the local immune system in the reproductive tract of the mare.
Research in Veterinary Science 38 88-95. (https://doi.org/10.1016/ S0034-5288(18)31853-8)

Widders PR, Warner S \& Huntington PJ 1995 Immunisation of mares to control endometritis caused by Streptococcus zooepidemicus. Research in Veterinary Science 58 75-81. (https://doi.org/10.1016/00345288(95)90093-4)

Witte TS, Bergwerff AA, Scherpenisse P, Drillich M \& Heuwieser W 2010 Ceftiofur derivates in serum and endometrial tissue after intramuscular administration in healthy mares. Theriogenology 74 466-472. (https:// doi.org/10.1016/j.theriogenology.2010.02.030)

Witte TS, Hahn K \& Duerr S 2018 Concentrations of gentamicin in serum, intrauterine fluid, and endometrial tissue after intravenous administration in healthy mares. Journal of Equine Veterinary Science 66 115. (https:// doi.org/10.1016/j.jevs.2018.05.160)

Wolf CA, Maslchitzky E, Gregory RM, Jobim MI \& Mattos RC 2012 Effect of corticotherapy on proteomics of endometrial fluid from mares susceptible to persistent postbreeding endometritis. Theriogenology 77 1351-1359. (https://doi.org/10.1016/j.theriogenology.2011.10.042)

Woodward EM \& Troedsson MHT 2015 Inflammatory mechanisms of endometritis. Equine Veterinary Journal 47 384-389. (https://doi. org/10.1111/evj.12403)

Woodward EM, Christoffersen M, Campos J, Squires EL \& Troedsson MHT 2012 Susceptibility to persistent breeding-induced endometritis in the mare: relationship to endometrial biopsy score and age, and variations between seasons. Theriogenology 78 495-501. (https://doi.org/10.10 16/j.theriogenology.2012.02.028)

Woodward EM, Christoffersen M, Campos J, Betancourt A, Horohov D, Scoggin KE, Squires EL \& Troedsson MHT 2013a Endometrial inflammatory markers of the early immune response in mares susceptible or resistant to persistent breeding-induced endometritis. Reproduction 145 289-296. (https://doi.org/10.1530/rep-12-0452)

Woodward EM, Christoffersen M, Campos J, Horohov DW, Scoggin KE, Squires E \& Troedsson MHT 2013b An investigation of uterine nitric oxide production in mares susceptible and resistant to persistent breedinginduced endometritis and the effects of immunomodulation. Reproduction in Domestic Animals 48 554-561. (https://doi.org/10.1111/rda.12124)

Woodward EM, Christoffersen M, Horohov D, Squires EL \& Troedsson MHT 2015 The effect of treatment with immune modulators on endometrial cytokine expression in mares susceptible to persistent breeding-induced endometritis. Equine Veterinary Journal 47 235-239. (https://doi. org/10.1111/evj.12266)

Xie H, Wei Z, Ma C, Li S, Liu X \& Fu Q 2018 Characterization of SeseC_01411 as a surface protective antigen of Streptococcus equi ssp. zooepidemicus. Research in Veterinary Science 118 517-521. (https:// doi.org/10.1016/j.rvsc.2018.05.007)

Yahya MFZR, Alias Z \& Karsani SA 2018 Antibiofilm activity and mode of action of DMSO alone and its combination with afatinib against Gram-negative pathogens. Folia Microbiologica 63 23-30. (https://doi. org/10.1007/s12223-017-0532-9)

Yi L, Wang Y, Ma Z, Zhang H, Li Y, Zheng JX, Yang YC, Fan HJ \& Lu CP 2014 Biofilm formation of Streptococcus equi ssp. zooepidemicus and comparative proteomic analysis of biofilm and planktonic cells. Current Microbiology 69 227-233. (https://doi.org/10.1007/s00284-014-0574-z) Youngquist RS, Blanchard TL, Lapin D \& Klein W 1984 The effects of EDTATris infusion on the equine endometrium. Theriogenology 22 593-599. (https://doi.org/10.1016/0093-691x(84)90059-1)

Zafraca AM 1975 Candida infection of the genital tract in Thoroughbred mares. Journal of Reproduction and Fertility: Supplement 23 349-351.

Zent W, Troedsson MHT, JL \& X 1998 Postbreeding uterine fluid accumulation in a normal population of thoroughbred mares: a field study Proceedings of American Association of Equine Practitioners 44 64-65.

Received 8 October 2019

First decision 4 November 2019

Revised manuscript received 6 August 2020

Accepted 14 August 2020 